\title{
Vibrio spp.: Life Strategies, Ecology, and Risks in a Changing Environment
}

\author{
Ana Sampaio ${ }^{1,2, *(\mathbb{D}}$, Vanessa Silva ${ }^{3,4,5}$, , Patrícia Poeta ${ }^{3,4,5}$ and Florin Aonofriesei ${ }^{6, *}$
}

Citation: Sampaio, A.; Silva, V.; Poeta, P.; Aonofriesei, F. Vibrio spp.: Life Strategies, Ecology, and Risks in a Changing Environment. Diversity 2022, 14, 97. https://doi.org/ $10.3390 / \mathrm{d} 14020097$

Academic Editor: Michael Wink

Received: 22 December 2021

Accepted: 27 January 2022

Published: 29 January 2022

Publisher's Note: MDPI stays neutral with regard to jurisdictional claims in published maps and institutional affiliations.

Copyright: (C) 2022 by the authors. Licensee MDPI, Basel, Switzerland. This article is an open access article distributed under the terms and conditions of the Creative Commons Attribution (CC BY) license (https:// creativecommons.org/licenses/by/ $4.0 /)$.
1 Department of Biology and Environment, University of Trás-os-Montes and Alto Douro (UTAD), Quinta de Prados, 5000-801 Vila Real, Portugal

2 Centre for the Research and Technology of Agro-Environmental and Biological Sciences (CITAB), University of Trás-os-Montes and Alto Douro (UTAD), Quinta de Prados, 5000-801 Vila Real, Portugal

3 MicroART-Microbiology and Antibiotic Resistance Team, Department of Veterinary Sciences, University of Trás-os-Montes and Alto Douro (UTAD), 5000-801 Vila Real, Portugal; vanessasilva@utad.pt (V.S.); ppoeta@utad.pt (P.P.)

4 Associated Laboratory for Green Chemistry (LAQV-REQUIMTE), University NOVA of Lisboa, Caparica, 2829-516 Lisboa, Portugal

5 Veterinary and Animal Research Centre, Associate Laboratory for Animal and Veterinary Science (AL4AnimalS), University of Trás-os-Montes and Alto Douro (UTAD), 5000-801 Vila Real, Portugal

6 Faculty of Natural Sciences and Agricultural Sciences, Department of Biology-Ecology, Ovidius University of Constanta, 1, University Street, 900470 Constanta, Romania

* Correspondence: asampaio@utad.pt (A.S.); florin.aonofriesei@gmail.com (F.A.); Tel.: +351-259350370 (A.S.); $+40-754297598$ (F.A.)

Abstract: Vibrios are ubiquitous bacteria in aquatic systems, especially marine ones, and belong to the Gammaproteobacteria class, the most diverse class of Gram-negative bacteria. The main objective of this review is to update the information regarding the ecology of Vibrio species, and contribute to the discussion of their potential risk in a changing environment. As heterotrophic organisms, Vibrio spp. live freely in aquatic environments, from marine depths to the surface of the water column, and frequently may be associated with micro- and macroalgae, invertebrates, and vertebrates such as fish, or live in symbiosis. Some Vibrio spp. are pathogenic to humans and animals, and there is evidence that infections caused by vibrios are increasing in the world. This rise may be related to global changes in human behavior (increases in tourism, maritime traffic, consumption of seafood, aquaculture production, water demand, pollution), and temperature. Most likely in the future, Vibrio spp. in water and in seafood will be monitored in order to safeguard human and animal health. Regulators of the microbiological quality of water (marine and freshwater) and food for human and animal consumption, professionals involved in marine and freshwater production chains, consumers and users of aquatic resources, and health professionals will be challenged to anticipate and mitigate new risks.

Keywords: aquatic ecosystems; heterotrophy; microalgae; macroalgae; marine animals; symbiosis; human pathogens; health risks

\section{Introduction}

Vibrios are Gram-negative bacteria, typically with lipopolysaccharide in the outer membrane, that belong to the Proteobacteria phylum, Gammaproteobacteria class, the most diverse class of Gram-negative bacteria. Among the Vibrionales order, the Vibrionaceae family comprises aquatic bacteria, mostly living in warm waters that tolerate different levels of salinity, including fresh, brackish, and marine waters [1].

The Vibrionaceae family includes the genera Aliivibrio, Catenococcus, Enterovibrio, Grimontia, Listonella, Photobacterium, Salinivibrio, and Vibrio [2], and is a genomically, phylogenetically, and functionally diverse group with comma- or curved rod-shaped motile bacteria, most with polar flagellation. These family members are heterotrophic bacteria 
widely distributed in aquatic environments, occupying niches in freshwater, estuarine, and marine ecosystems, as well as in aquaculture systems, and contributing to nutrient cycling [3-6]. They are chemoorganotrophic and use both aerobic respiration and fermentation of sugars producing acids (formic, lactic, acetic, succinic acids), ethanol, and pyruvate [7]. Unlike in Enterobacteriaceae, fermentation sugar tests have limited importance in Vibrio spp., because they ferment few sugars and their profile utilization is highly variable.

The genus Vibrio has the largest number of species, and currently 147 Vibrio species and 4 subspecies are recognized [8] of which less than a dozen are human pathogens (e.g., Vibrio cholera, Vibrio parahaemolyticus, Vibrio vulnificus). Other Vibrio spp. infect marine animals, such as fishes, shrimps, corals, and crustaceans [9-13], but the majority are nonpathogenic species and some of them are symbionts (Table 1). The etymology of Vibrio originates from the word vibro, which means to vibrate with tremulous motion, and was given to the species in 1854 by Pacini when he published his work on Asiatic cholera [14].

Table 1. Sources of some Vibrio spp. pathogenic to humans and to animals or that are symbionts.

\begin{tabular}{|c|c|c|c|}
\hline Vibrio Species & Environments & Hosts & Pathology \\
\hline V. alginolyticus ${ }^{1}$ & seawater, human, seafood & human & $\begin{array}{c}\text { wound, ear/eye and soft tissue } \\
\text { infections }\end{array}$ \\
\hline $\begin{array}{l}\text { V. anguillarum } \\
\text { V. carchariae }\end{array}$ & $\begin{array}{c}\text { seawater, marine animals } \\
\text { seawater, shark }\end{array}$ & $\begin{array}{c}\text { salmon, bivalves } \\
\text { shark?, human (shark bite) }\end{array}$ & $\begin{array}{c}\text { vibriosis, septicemic disease } \\
\text { human (shark bite) }\end{array}$ \\
\hline V. cholerae $^{1}$ & $\begin{array}{c}\text { fresh and brackish waters, } \\
\text { invertebrates, algae, aquatic } \\
\text { animals }\end{array}$ & human & $\begin{array}{l}\text { cholera: dehydration and } \\
\text { electrolyte loss }\end{array}$ \\
\hline$V$ corallilyticus $^{2}$ & coral & zooxanthellae & coral bleaching \\
\hline V. damsela ${ }^{3}$ & seawater, fish & fish, human & wound infections \\
\hline$V$. fluvialis & water, oyster & human & diarrhea, gastroenteritis \\
\hline$V$. furnissii & estuarine water & human & $\begin{array}{l}\text { acute gastroenteritis (rare in } \\
\text { clinic) }\end{array}$ \\
\hline V. harveyi & seawater & shrimp, invertebrates, human & vibriosis \\
\hline V. hollisae & water, seafood & human & diarrhea \\
\hline$V$. mediterranei & seawater, coral endosymbiont & zooxanthellae & coral bleaching \\
\hline V. metschnikovii & $\begin{array}{l}\text { fresh, brackish, marine waters, } \\
\text { seafood }\end{array}$ & human (rarely) & wound infections? \\
\hline V.mimicus & water, seafood, birds & human & diarrhea \\
\hline V. parahaemolyticuss ${ }^{1}$ & seafood & human & acute gastroenteritis \\
\hline V. salmonicida ${ }^{4}$ & seawater, marine fishes & salmon, rainbow trout & cold-water vibriosis \\
\hline V. shiloi & coral endosymbiont & zooxanthellae & coral bleaching \\
\hline V. symbiont & pufferfish & & toxic to humans and animals \\
\hline V. tubiashi & seawater, marine mollusks & Pacific oysters, bivalves & vibriosis \\
\hline V. vulnificus ${ }^{1}$ & $\begin{array}{l}\text { estuarine and seawaters, } \\
\text { seafood, sediment }\end{array}$ & human & $\begin{array}{l}\text { fulminant septicemia, wound } \\
\text { infections }\end{array}$ \\
\hline
\end{tabular}

${ }^{1}$ Common human pathogenic species; ${ }^{2}$ thermodependent pathogen of a tropical coral species [15]; ${ }^{3}$ presently Photobacterium damselae; ${ }^{4}$ psychrophilic species.

Most Vibrio species, if not all, have two circular chromosomes with distinct sizes and numerous cryptic plasmids [16]. Vibrio spp. are highly heterogeneous and polyphyletic [17]. Actually, the 8-gene multilocus sequence analysis (MLSA) defines 23 clades for Vibrio and Photobacterium $[18,19]$.

Biochemically, the majority of Vibrio spp. are oxidase, indole, and citrate positive, capable of reducing nitrate to nitrite and hydrolyzing urea and degrading gelatin, starch, lipids, chitin, and alginate with extracellular enzymes [20,21].

Vibrio species have the fastest growth rates among bacteria, responding almost immediately to favorable environmental conditions such as high temperature, salinity, and dissolved oxygen [22,23]. Physiologically, almost all species are halophilic, requiring salt in a concentration that varies with the species $(\mathrm{NaCl} 1-12 \%)$, except $V$. cholerae, $V$. fluvialis, $V$. furnissii, and $V$. mimicus, which grow on nutrient agar. They usually, inhabit brackish and 
sea waters [20]. Vibrios are eurythermic $\left(5^{\circ} \mathrm{C}\right.$ to $\left.>40^{\circ} \mathrm{C}\right)$, preferring warm waters $\left(>18^{\circ} \mathrm{C}\right)$ and alkaline conditions ( $\mathrm{pH}$ 6.5-9.0) [24].

Vibrios are heterotrophic bacteria that swim freely in the water column [25], live in association with other organisms [10,26], and can achieve symbiosis [27]. This diversity of biological niches in the aquatic environment is only possible because Vibrio spp. are motile bacteria, and have the ability to sense and communicate chemically. At the microscale level, chemotaxis ensures the orientation towards the optimal habitat based on the chemical signals emitted by different niches. Free-living vibrios can move either to areas with soluble attractants or to the many particles in the water column.

Under certain environmental conditions, such as those with limited nutrients, freeliving vibrios can attach to different surfaces and form biofilms. These communities of "swarmer cells" embedded in a polysaccharide matrix can better withstand some adverse factors in the external environment [25,28]. While undergoing chemotaxis and showing the ability to form biofilms, vibrios in unfavorable environmental conditions such as low temperature, low salinity, and starvation, enter in a state of latency, lose their ability to grow, and became uncultivable, although the cells are still viable [29]. Viable but nonculturable (VBNC) cells are characterized by the inability to grow on laboratory media. This makes their detection impossible with usual culture methods. Compared to culturable cells, VBNC cells have alterations in their morphology, cell wall structure, membrane composition, cell physiology, and metabolism. VBNC cells are physically and chemically more resilient than cultivable cells. The VBNC state has an important impact on Vibrio spp. monitoring based on culture methods, leading to an underestimation in environmental or clinical samples, and thus poses a risk to public health [29]. Due to this fact, the use of independent-culture methods in these areas should be considered [30].

Species of Vibrio are present in all aquatic environments, especially the saline ones, and are capable of growth as a free-living organism, in association and in mutualism/symbiosis with many aquatic organisms. They have the ability to adapt and respond fast to environmental changes. Vibrio spp. seem to benefit from a changing world, and can alter or undermine the close relationship between humans and aquatic systems.

The main goal of this review was to update the information regarding the distribution and the ecology of Vibrio spp., and contribute to the discussion of their potential risks in a changing environment.

\section{Vibrio as an Heterotroph-Free Living Way of Life}

All Vibrio species are aquatic heterotrophs living between the sediments and the water column. Frequently Vibrio spp. live freely in aquatic environments, albeit their frequency varies with the aquatic ecosystem and niche. Vibrios are also agents of organic matter mineralization, playing an important role in organic matter recycling due to their enzymes, which allow them to use a wide variety of substrates [31]. They can hydrolase carbohydrates, lipids, and proteins and have the capacity to break down polymers such gelatin, collagen, starch, chitin, alginate, lignin, and hydrocarbons, contributing to the recycling of carbon and nitrogen in aquatic environments. Additionally, vibrios can produce polyunsaturated fatty acids, essential compounds for the aquatic food web organisms that they cannot synthesize [32]. Vibrios themselves can be a food source for flagellates and thus contribute to the recycling of organic matter in aquatic environments [33].

Temperature and salinity are known to affect Vibrio species' density and diversity. While Vibrio spp. are eurythermic $\left(5^{\circ} \mathrm{C}\right.$ to $\left.>40^{\circ} \mathrm{C}\right)$ and worldwide distributed, they prefer warm waters $\left(>18{ }^{\circ} \mathrm{C}\right)$ and warmer periods and seasons, a trait that can explain their seasonal peaks. Of all the Vibrio spp. (more than 100), only a few are able to live in low salinity conditions: $V$. cholerae, $V$. fluvialis, $V$. furnissii, and $V$. mimicus.

In temperate and cold climates, Vibrio spp. density is higher in summer than in winter (Table 2), as observed in sea and estuarine waters located in the North Sea, Germany [34,35]. Despite the general relationship observed between the presence and abundance of Vibrio spp. in higher water temperatures, species have specific responses to temperature: some 
prevail the whole year, while others were only detected at a specific temperature range, or are less affected by this parameter. V. alginolyticus and V. parahaemolyticus were both found to be present even at temperatures around freezing point [35].

Table 2. Free-living Vibrio spp. reported densities, niches, and geographic locations. UFC: colony forming units; MPN: most probable number; PCR-m: PCR-multiplex; FISH-fluorescence in situ hybridization; fresh (FW), brackish (BW), estuary (EW), sea (SW) and tidal (TW) waters, sediment (S); $\mathrm{Va}=V$. alginolyticus; $\mathrm{Van}=V$. anguillarum; $\mathrm{Vc}=V$. cholerae $; \mathrm{Vf}=V$. fluvialis $;$. harveyi $=\mathrm{Vh} ; \mathrm{Vm}=V$. mimicus; $V$. natriegens $=\mathrm{Vn} ; \mathrm{Vp}=V$. parahaemolyticus; $\mathrm{Vv}=V$. vulnificus; ref. -reference.

\begin{tabular}{|c|c|c|c|c|}
\hline Niche & Density & Method & $\begin{array}{c}\text { Vibrio spp. Prevalence } \\
(\%)\end{array}$ & Country [Ref.] \\
\hline $\begin{array}{c}\text { Port areas } \\
\text { Ballast tanks } \\
\text { Coastal waters }\end{array}$ & $\begin{array}{l}1-4.4 \times 10^{3} \mathrm{UFC} / \mathrm{mL} \\
1-4.3 \times 10^{2} \mathrm{UFC} / \mathrm{mL} \\
2-1.6 \times 10^{3} \mathrm{UFC} / \mathrm{mL}\end{array}$ & PCR-m & $\begin{array}{c}\mathrm{V}_{c}(24) ; \mathrm{V}_{c} \mathrm{O} 1(\operatorname{ctx} A C \\
\operatorname{tcp} A C) \\
\mathrm{Vc} \mathrm{O} 1(\operatorname{ctx} A C, t c p A C)\end{array}$ & Brazil [36] \\
\hline $\begin{array}{l}\text { FW } \\
\text { BW }\end{array}$ & Not presented & MPN-PCR & $\begin{array}{c}\mathrm{Vc}_{\mathrm{c}}(34), \mathrm{Vm}(19) \\
\mathrm{Vp}(51), \mathrm{Va}(46), \mathrm{Vm} \\
(28)\end{array}$ & South Africa [23] \\
\hline $\begin{array}{c}\text { TW } \\
\operatorname{Mud}(\mathrm{M})\end{array}$ & $\begin{array}{c}1.4 \times 10^{1}-5.0 \times 10^{4} \\
\mathrm{MPN} / \mathrm{mL} \\
2.1 \times 10^{2}-2.7 \times 10^{2} \\
\mathrm{MPN} / \mathrm{mL}\end{array}$ & Culture & $\begin{array}{c}\text { Va, Vp } \\
\text { Va (46), Vp, Vc, Vv }\end{array}$ & South Korea [37] \\
\hline SW & $\begin{array}{l}5 \times 10^{2}-3.4 \times 10^{4} \\
\text { cells } / \mathrm{mL}\end{array}$ & FISH & Vibrio spp. & $\begin{array}{c}\text { Germany, North Sea } \\
{[34]}\end{array}$ \\
\hline $\begin{array}{c}\text { EW } \\
\text { S }\end{array}$ & $\begin{array}{c}0-8.4 \times 10^{2} \mathrm{UFC} / \mathrm{mL}^{*} \\
0-2.9 \times 10^{3} \mathrm{UFC} / \mathrm{g} \text { * }\end{array}$ & Culture and PCR & $\begin{array}{c}\text { Va and Vp (all year), } \\
\text { Vv (summer), Vc (very } \\
\text { low) }\end{array}$ & $\begin{array}{c}\text { Germany, North Sea } \\
{[35]}\end{array}$ \\
\hline $\begin{array}{c}\text { SW } \\
\text { Lagoon }\end{array}$ & $\begin{array}{c}\text { 0-log6.4 gene } \\
\text { copies } / 100 \mathrm{~mL} \text { * } \\
\text { 0-log8.32 gene } \\
\text { copies } / 100 \mathrm{~mL} \text { * }\end{array}$ & $\begin{array}{l}\text { Culture and real time } \\
\text { PCR }\end{array}$ & $\begin{array}{c}\text { Vv }(14.9, \\
\text { July-September), Vc } \\
\text { (33.6, June-September), } \\
\text { Van (2.5, May and } \\
\text { June), Vf (1.5, July) }\end{array}$ & $\begin{array}{l}\text { Lithuania, Baltic Sea } \\
\text { [38] }\end{array}$ \\
\hline $\begin{array}{l}\text { SW } \\
\text { FW }\end{array}$ & Not presented & Culture & $\begin{array}{c}\mathrm{Vv}(41), \mathrm{Vp}(33), \mathrm{Va}(15) \\
\mathrm{Vn}(4), \text { and } \mathrm{Vh}(0.7) \\
\text { non-01 Vc }(80), 01 \mathrm{Vc} \\
(13.1), \mathrm{Vm}(2.6)\end{array}$ & Iran, Caspian Sea [39] \\
\hline SW & $0-1.2 \times 10^{5} / \mathrm{L}^{*}$ & MPN-PCR & $\mathrm{Vc}_{\mathrm{c}} \mathrm{Vp}, \mathrm{Vv}$ & Guinea-Bissau [40] \\
\hline EW & $\begin{array}{c}2.3 \times 10^{5}-2.4 \times 10^{12} \\
\mathrm{MPN} / 100 \mathrm{~mL}\end{array}$ & MPN & $\begin{array}{l}15 \text { Vibrio spp.; Vp (16), } \\
\text { Vc (14.5), Va (13) }\end{array}$ & Brazil [41] \\
\hline
\end{tabular}

* Depending on Vibrio spp.

In a study that took place along the Central Wadden Sea coast over a 2-year period, $V$. alginolyticus and $V$. parahaemolyticus were always present, while $V$. vulnificus was only detected at temperatures between $14{ }^{\circ} \mathrm{C}$ and $26.5^{\circ} \mathrm{C}$. Vibrio spp. and salinity were not significantly correlated, and $V$. cholera did not have a seasonal pattern [35]. Another investigation in the Lithuanian Baltic Sea, in coastal lagoon bathing sites, Vibrio spp. densities (in gene copies $/ 100 \mathrm{~mL}$ ) varied over the sampling months and the aquatic systems: $V$. vulnificus density was high in coastal samples from July to September, while V. cholera was present in both fresh and marine water bodies from June to September, but reached the highest values at lagoon sites, with lower salinity values. V. anguillarum and V. fluvialis were underrepresented and only detected in coastal waters [38].

In South Carolina detention ponds, Vibrio spp. were generally more abundant in the warmer months, reaching maximum abundances during the summer of 2009, when water temperatures ranged from $29.5-31.5^{\circ} \mathrm{C}$. Temperature was positively and significantly correlated with V. vulnificus [42]. A survey of the Vibrio community carried out in 2016 (May 
to December) in the Neuse river estuary (USA), by using culture-independent methods showed that this community reflected seasonal and storm-related changes in the water column. These alterations were more dramatic after Hurricane Matthew, which was responsible for a supply of nutrients to the estuary [43].

In an extensive survey of Vibrio species from 2006 to 2009, in Black Sea coastal and inland waters (Georgia), 1440 water samples were analyzed and 1595 presumptive Vibrio isolates were collected (657 from four sites on the Black Sea coast and 938 from three inland water reservoirs). In the Black sea sites, Vibrio diversity was slightly higher compared to freshwater samples, and 10 of the putative clinically important Vibrio spp. were analyzed by PCR. Among PCR-confirmed species, V. cholerae (O1 and possible O139) was most prevalent (64.6\%), followed by V. parahaemolyticus (21.4\%), V. vulnificus (4.0\%), and V. alginolyticus (2.6\%). Six species ( $V$. metschnikovii, $V$. harveyi, $V$. furnissii, $V$. fluvialis, $V$. cincinnatiensis, and $V$. mimicus) accounted for $4.4 \%$ of samples. The water temperature was positively correlated with the abundance of Vibrio spp. (except V. metschnikovii), and salinity was correlated with Vibrio community composition [44].

Temperature drives the frequency of Vibrio spp. isolation [23], especially in freshwater and in temperate climates. In contrast, in equatorial and tropical aquatic systems the correlation between Vibrio quantities and temperature is often absent, since the temperature variability is low, and salinity emerges as an important factor regulating Vibrio spp. distribution and dynamics.

In an estuary located in the Gulf of Mexico, $V$. vulnificus was detected throughout the year, but the highest values $\left(5.14 \times 10^{3} \mathrm{CFU} / 100 \mathrm{~mL}\right)$ were found in September, at warmer temperatures and moderate salinities [45]. In a study in Guinea Bissau, the abundance of $V$. vulnificus and $V$. parahaemolyticus was negatively correlated with salinity [40]. $V$. cholerae was also detected in coastal water samples throughout the wet season, reaching higher concentrations by the end of this season $\left(1.2 \times 10^{4} \mathrm{MPN} / \mathrm{L}\right)$. V. parahaemolyticus was detected simultaneously, while $V$. vulnificus was detected only by the end of the wet season. For the three species, genotypes associated with virulence were found: ctxA+ $V$. cholera (twice), enteropathogenic (tdh+ and trh+) V. parahaemolyticus at concentrations up to $1.2 \times 10^{3} \mathrm{MPN} / \mathrm{L}$, and $V$. vulnificus (vvhA) detected in all surveyed sites, up to $1.2 \times 10^{5} \mathrm{MPN} / \mathrm{L}$ [40]. In a survey conducted during April and September 2001 in the Caspian Sea (Golestan, a province of Iran), 100 Vibrio isolates were recovered from 73 water samples, and V. vulnificus, V. parahaemolyticus, and V.alginolyticus were the most frequent species, with 39, 32, and 17 isolates, respectively. Much less frequent were $V$. damsela (1 isolate), and $V$. harveyi (1 isolate) [39].

During a 1-year study of the pathogenic Vibrio spp. distribution in tidal waters (TW) and mud, samples were taken from environments of the southern coast in South Korea. The study observed that MPN/mL of presumptive Vibrio spp. was affected by season, but not by location, despite the differences in land use and human population density at the sampling sites [37]. The sampling months had different temperature and $\mathrm{pH}$ values for TW and mud, salinity, and biological oxygen demand (BOD) in TW. Among the sampling months, Vibrio spp. MPN values were significantly correlated with temperature and $\mathrm{pH}$ in both TWs and mud samples, and with salinity and BOD in TW. In TWs, Vibrio spp. density was negatively correlated with temperature, salinity, EC, and turbidity. From a total of 10,983 isolates, V. alginolyticus and V. parahaemolyticus were ubiquitous in both niches, and season-independent, in contrast to $V$. cholerae and $V$. vulnificus, which specifically related to summer. While $V$. parahaemolyticus was isolated throughout the year, the pathogenic strains were detected only in June and September. All the $V$. cholerae isolates were nontoxigenic (non-O1 and non-139), but $88 \%$ of the $V$. vulnificus isolates possessed an elastolytic protease as a virulence factor [37]. The seasonality of potential pathogenic Vibrio spp. may threaten seafood safety and increase the risk of illness in South Korea, where local people consume raw fish during warmer months [37].

A freshwater intrusion into saltwater body the Mississippi Sound after the opening of the Bonnet Carre Spillway deeply affected the ecology of Vibrio spp., albeit temporarily. The 
densities of $V$. parahaemolyticus and $V$. vulnificus decreased while the density of $V$. cholerae increased, becoming the dominant species. The authors found a significant relationship between the MPN densities and salinity for each one of the three Vibrio spp. At salinity levels of $6 \mathrm{ppt}, V$. cholerae was the only Vibrio detected [46]. Other studies reported negative $(p<0.05)$ correlations between $V$. parahaemolyticus and salinity [42].

Nevertheless, many reports have not found any correlation between temperature and/or salinity and Vibrio density $[41,47,48]$, suggesting that this parameter can be related with other physicochemical parameters [41]. Organic matter and nutrient enriched environments support high Vibrio densities [49] that may be related to anthropogenic activities. Dissolved oxygen (DO), chemical oxygen demand (COD), and BOD are strong related to Vibrio spp. densities. Vibrio spp. had higher densities in freshwater samples near facilities that dumped untreated effluents or wastes from domestic houses, fish slaughterhouses, shrimp farming, and droppings from domestic and wild animals [23,41,50-52]. In South Korea, BOD and $\mathrm{pH}$ were positively correlated with Vibrio spp., expressed as MPN/mL, in TW samples, while temperature, salinity, and turbidity were negatively correlated [37].

Along the Zuari estuary on the central west coast of India and during three seasons (pre-monsoon, monsoon, and post-monsoon), organic matter determined the distribution of Vibrio spp., with high values during the monsoon, probably due the terrestrial runoff [53]. In Guinea Bissau, the abundance of Vibrio spp. (V. cholera, V. parahaemolyticus, and V. vulnificus) was positively correlated with total suspended solids (TSS) and precipitation [40]. In the North Sea, total organic carbon (TOC) was positively correlated with the abundance of benthic $V$. alginolyticus and $V$. parahaemolyticus, as well as with rainfall, probably due to nutrient input into the watershed [35]. In Ceará, Brazil, in water samples taken from the Coreaú estuary between June and October 2005, the MPN of vibrios per $100 \mathrm{~mL}$ ranged from $2.3 \times 10^{5}$ to $2.4 \times 10^{13}$. The high abundance recorded was probably related to several anthropogenic activities such as shrimp farming, tourism, agriculture, and animal husbandry [41]. The highest MPN values were found in samples with high $\mathrm{pH}(\sim 8.2)$ and, among the environmental variables tested (temperature, $\mathrm{pH}$ and salinity), $\mathrm{pH}$ was the only one positively correlated with Vibrio MPN.

In South Carolina in the detention ponds and receiving tidal creeks between April 2008 and August 2009, the abundance of $V$. parahaemolyticus and V. vulnificus were positively $(p<0.05)$ correlated with silicate, total dissolved nitrogen, dissolved organic nitrogen, total phosphorus, and total dissolved phosphorus. The abundance of $V$. vulnificus was negatively $(p<0.05)$ correlated with DO. Vibrio spp. abundances were not correlated with chlorophyll a, suspended solids, or inorganic N concentrations [42].

The beach sands and sediments of coastlines are the sources of microorganisms for the water column [54]. From Tel Aviv beaches in the Mediterranean, several pathogenic vibrios were recovered [55]. In heavily polluted sites such as the Gaza Strip, high concentrations of fecal indicators and potentially pathogenic Salmonella and Vibrio species were found. In sands, Vibrio reaches higher densities than in water, and its occurrence was correlated $(p<0.013)$ with yeast and molds [56]. Along the Nigerian coastline, water and sand samples retrieved from recreational beaches were contaminated with fecal indicator bacteria (FIB), and with many pathogens, among them $V$. parahaemolyticus and $V$. vulnificus [57].

Freshwater is essential for life and human activities, and is scarce and under pressure. As most Vibrio spp. are halophilic, the probability of finding them in freshwater ecosystems is considered low, which may explain why studies on their prevalence in freshwater are few when compared to other environments [23].

Under favorable conditions, vibrios are opportunistic organisms capable of using a wide range of resources [58]. Their association with other aquatic organisms, by colonizing body surfaces or establishing pathogenic or symbiotic relationships, can favor Vibrio spp. survival. 


\section{Vibrio spp. Associated with Micro- and Macroalgae}

Both in situ observations as well as mesocosm studies indicated the constant association of vibrios with dense populations of microalgae. This generates complex interactions between the heterotrophic vibrios and other organisms often located at different trophic levels [59]. During microalgal blooms a large amount of nutrients is released in dissolved and particulate forms, maintaining high vibrios densities [60]. The agglomeration of microalgae during the blooms also provides a large area of attachment for vibrios, which contributes to the diversification of biological niches [61].

There is some evidence that algae enhance Vibrio spp. survival and growth. The increased numbers of harmful algal blooms (HABs) over recent decades have often been followed by an increase in the Vibrio spp. population. From 2008 to 2009, five HABs were studied in coastal storm water detention ponds located in South Carolina. Two blooms occurred during warmer months, in August and November 2008, respectively a cyanobacteria and a dinoflagellate bloom, and three during cooler months (December 2008 to February 2009), caused by dinoflagellates and euglenophytes. After the blooms in warmer months, Vibrio spp. increased. By contrast, after the blooms in cooler months, Vibrio spp. did not increase. In August 2008, the bloom was dominated by Cylindrospermopsis raciborskii, followed by Anabaena sp. and was followed by an increase in both $V$. parahaemolyticus and $V$. vulnificus. Later, in November, a Heterocapsa rotundata bloom was observed on three ponds, and it was followed by an increase of $V$. parahaemolyticus copies/100 mL [42].

In a survey of the Vibrio community carried out by Jesser and Noble [43], they found positive correlations between some Vibrio species and algae photopigments: (i) V. parahaemolyticus, $V$. ordalii, V. cholerae, $V$. mimicus, and $V$. alginolyticus had positive correlations with peridinin, the dinoflagellates pigment; (ii) $V$. cholerae was correlated $(\mathrm{r}=0.47)$ with fucoxanthin, present in brown seaweeds, diatoms, and dinoflagellates, and total chlorophyll a $(\mathrm{r}=0.40)$; (iii) $V$. parahaemolyticus correlated $(\mathrm{r}=0.41)$ with zeaxanthin from cyanobacteria. In contrast, $V$. vulnificus and $V$. fluvialis were negatively correlated with all pigments measured, especially with zeaxanthin $(r=-0.46$ and $r=-0.49$, respectively). Each Vibrio spp. has a unique dynamic, depending on the season, responding individually to events. This suggest that the provisions based on total Vibrio abundance may be insufficient for risk assessments of potentially pathogenic species [43].

To determine the microbiological hazards of ballast water tanks (BWs) transported to Brazilian ports, Vibrio concentration and toxigenic V. cholerae $\mathrm{O} 1$ occurrence were analyzed in water samples taken from BWTs of ships on arrival, and harbors and waters along the Brazilian coastline. At a temperature range of $1-32{ }^{\circ} \mathrm{C}$ and in all environments, the free-living vibrios were less abundant $(18 \%)$ than vibrios associated with plankton $(32 \%)$. Plankton vibrios varied from $<10-5.1 \times 10^{3} \mathrm{CFU} / \mathrm{mL}$ while free-living vibrios varied from $<1$ to $4.3 \times 10^{2} \mathrm{CFU} / \mathrm{mL}$. Mean vibrio values were unaffected by the salinity gradient (0.1-39.5 psu) recorded in BWs [36]. V. cholerae was found in BWs $(9.5 \%)$ and in port samples $(24.2 \%)$, as free-living and attached forms. The toxigenic strains $V$. cholerae $\mathrm{O} 1$ (ctxAC, tcpAC), involved in cholera disease, were found in BWs $(2 \%)$ and harbor (2\%) samples, confirming that ballast tanks are important carriers of pathogenic organisms, and that monitoring these or other pathogenic bacteria is very importance in BWs management programs.

Macroalgae are cultured in many parts of the world, for cooking and folk medicine. In China alone, about 6 million tons wet weight of Saccharina japonica kelp are planted each year [62]. Recently, a study demonstrated that $V$. parahaemolyticus was detected by molecular methods in the edible Saccharina latissima in $78 \%$ of enriched kelp samples, indicating that bacterial pathogens vary on the algae thallus surface and in the surrounding water. This study was the first food safety assessment of edible sea macroalgae in the Northeast USA, providing data on the importance of monitoring microbial contamination in the edible macroalgae industry, and enabling its expansion [63]. 


\section{Vibrio spp. Associated with Zooplankton and Animals}

Vibrio spp. constitute a significant portion of the bacteria naturally associated with zooplankton, namely copepods [5,64]. Numerous studies have reported the association of vibrios with zooplankton, most often by colonizing the body surface of these organisms [65].

The formation of biofilm by Vibrio spp. on the exoskeleton of microcrustaceans and other marine organisms may in fact be a survival strategy $[26,66]$ because cells can more efficiently use nutrients absorbed into the biofilm matrix. In this way, vibrios can cope with harsh environmental changes, mainly those related to low nutrient concentrations. They can also withstand the action of toxic compounds and exchange useful compounds with other bacteria or hosts.

It is well known that vibrios are able to break down chitin, one of the richest sources of amino carbohydrates in oceans $[67,68]$. The chitin layer on the surface of copepods can be used as a nutrient [69]. The importance of the Vibrionaceae family in preventing the sinking of chitin to the ocean floor has long been recognized [70], but this polymer is besides a source of nutrients, and has a key role in the life strategies of several Vibrio spp. Chitin colonization by $V$. chloreae leads to biofilm production, which in turn induces competence in bacteria, favoring transformation and horizontal gene transfer [71], which are important to acquire virulence and antibiotic-resistant genes. Chitin also induces natural competence in other Vibrio spp. such as V. fischeri, V. parahaemolyticus, and V. vulnificus [72].

Numerous studies conducted by both culture-dependent and -independent methods indicated that the abundance of vibrios is high near or on the body of marine organisms, such as mollusks [73,74], fish [75,76], corals [77], and shrimp [78]. Other animals, such as waterbird species that inhabit and feed in aquatic systems, can be infected by their prey and might be vectors of $V$. cholerae [79].

In the Mollusca phylum, Bivalvia can accumulate a large number of vibrios and become vehicles for the transmission of pathogenic species [80]. The Vibrio species associated with natural mussel (Mytilus galloprovincialis) populations in Galicia (Spain) changed with the water temperature and salinity. Vibrio splendidus and V. aestuarianus were dominant during the warm and the cold seasons, respectively [81]. Marine sediments underlying farmed mussels support an enriched presence of vibrios relative to surrounding environments [49]. In nature, sediments are also important natural reservoirs for Vibrio spp. in Northeast Galicia [81]. Very recently, Lattos et al. [82] reported mass mortalities in the winter in the Pinna nobilis population in the Aegean Sea, in which V. splendidus and Vibrio mediterranei may be implicated.

Several Vibrio spp. are involved in coral bleaching, one of the most serious diseases affecting corals worldwide. The loss of the pigments in corals is due to the change of the symbiotic relationship between the host coral and unicellular algae of the zooxanthellae group [83-85]. The most well-known species involved in coral bleaching are V. coralliilyticus and Vibrio shilonii [86]. The infection is favored by the increase of seawater temperature, and has an extremely negative effect on corals and reef formation. The infection is initiated by the adhesion of bacteria on the surface of corals, followed by the penetration and the rapid growth inside the tissues, reaching up to $10^{9} \mathrm{CFU} / \mathrm{mL}$ in a short period of time. Once inside the coral tissues, $V$. shilonii cells remain virulent although they become VBNC $[77,87,88]$.

On Riou Island, in the northwestern Mediterranean Sea, massive disease outbreaks in benthic invertebrates occurred during an abnormal period of elevated seawater temperatures. One of the most affected species was the red gorgonian Paramuricea clavata, a colonial soft coral, and a key species in the communities dwelling in dim-lit habitats in the Mediterranean. Associated with the infection was a V. coralliilyticus strain that showed thermodependent virulence to $P$. clavata [15].

In benthic sea environments, and at different depths, sponges (Phyla Porifera) can be associated with Vibrio spp. At depths of 150 to 1242 feet ( 46 to $379 \mathrm{~m})$, sponges from distinct geographies live in commensalism with several Vibrio spp.: V. alginolyticus, Aliivibrio fischeri, and V. mediterranei, and some putative new species most closely related to $V$. ichthyoenteri and V. scophthalmi [89]. 
Barotolerant Vibrio spp. have been isolated from deep-sea sediments, including hydrothermal vents. At a depth of 4940 meters and 150 miles east of Cape Canaveral (formerly Cape Kennedy), samples were collected aboard the research vessel Eastward, and strains of Vibrio were isolated [90]. From the Polychaeta Alvinella pompejana collected from a deep-sea hydrothermal field (2600 $\mathrm{m}$ depth) in the East Pacific Rise, Vibrio diabolicus was isolated by the French-American cruiser Hero in 1991, and by the French-manned submersible Nautile [91]. Later, in 1999, along the East Pacific Rise, and during dives of the deep-sea submersibles Alvin and Nautile, water samples were collected at a depth of $2500 \mathrm{~m}$ and nearby sulfide chimneys of a hydrothermal vent community. Four mesophilic bacterial isolates were recovered from the samples, cultured and identified: Shewanella algae, $V$. harveyi, and one novel Vibrio species. The new species, Vibrio antiquarius, is closely related to $V$. alginolyticus, $V$. parahaemolyticus, and $V$. harveyi in a monophyletic clade [92].

Many of Vibrio spp. responsible for illness in marine organisms can be important pathogens for animals in aquaculture systems [93]. Within this group, the species $V$. anguillarum, $V$. salmonicida, and $V$. vulnificus can infect several species of fish, and $V$. harveyi causes massive economic loses in shrimp culture systems [94,95]. Disease in farmed fish and crustaceans is very common in the early stages of animals' life and can occur suddenly, causing mass mortality events [96-100]. Vibrionaceae diversity was investigated in Tunisia, in a Ruditapes decussatus hatchery located in the coastal marine waters, and V. alginolyticus was the predominant species ( $54 \%$ of the strains were isolated from the inside of larva and post-larva rearing structures), followed by $V$. fluvialis, $V$. vulnificus, $V$. cholerae, and $V$. parahaemolyticus [101].

The evaluation of Vibrio communities associated with seafood, integrating both culture -dependent and -independent methods, would be valuable in future. Although both methods detect $V$. parahaemolyticus and $V$. vulnificus in the Ruditapes philippinarum bivalve, the two methods proved to be complementary for the detection of $V$. alginolyticus and $V$. cholera [74]. The authors have proposed a reassessment of the marine agar medium for both the recovery of human Vibrio pathogenic species and for a screening approach in contaminated seafood [74]. Recently, a multiparametric approach to assess the water quality in a Mediterranean mariculture (Dicentrarcus labrax and Sparus aurata), reported that Vibrio diversity was higher in July than in December, and identified a set of Vibrio species critical to the health of the farming environment ( $V$. rotiferianus, $V$. parahemolyticus, $V$. harveyi, and V. vulnificus). Some of these species are also important for human health [102].

\section{Symbiotic Members of Vibrionaceae}

Several Vibrionaceae species are bioluminiscent and some of them enter into symbiotic relationships with fish and squid living in marine environments. The taxonomy of some species included in the Vibrio genus has been marked by ambiguity. Such an example is the Vibrio fischeri group, which comprises four species: V. fischeri, V. logei, V. salmonicida, and $V$. wodanis. Based on an analysis of $16 \mathrm{~S}$ rRNA gene sequences, Urbanczyk et al. [103] reclassified the group as a new genus, Aliivibrio, which contains the following species: Aliivibrio fischeri, Aliivibrio logei, Aliivibrio salmonicida, and Aliivibrio wodanis.

A similar situation was found for Photobacterium genus. A comprehensive study carried out on $16 \mathrm{~S}$ rRNA and multilocus sequence analysis revealed a clear discrimination between Photobacterium, on the one hand, and Aliivibrio and Vibrio, on the other [104]. Furthermore, the study showed the existence of two distinct clades within Photobacterium: (i) clade I, containing luminous species, some of which are able to enter into symbiotic relationships with fish and squid; (ii) clade II, containing non-luminous species [104]. However, for the description of species, we kept the old names as they are used in most studies. Photobacterium species are widespread in the marine environment and members of this genus have been isolated from a variety of habitats such as water columns, sediments, corals, and the skin and gut of marine animals [104]. Some species are able to establish symbioses with animals living in marine environments [105]. The genus Photobacterium includes about 20 species, seven of which produce luminiscence and, among these, only 
three enter into mutualistic associations with animals: P. kishitanii, P. leiognathi, and P. mandapamensis [104]. Photobacterium kishitanii establishes symbioses with deep-sea fish [106]. This species manifests close similarities with both P. phosphoreum and P. iliopiscarium; however, it forms a distinct clade within the Photobacterium genus [107]. P. leiognathi was isolated from the supraesophageal light organ of Nuchequula nuchalis, a fish species from the leiognathid group [106]. The bacteria inhabit a special soft tissue of the light organs of animals. The blue-green light is emitted by bacteria located in the ventral region of the fish. The light organ environment provides symbionts with nutrients and oxygen for growth and luminiscence. In their turn, the animals use the light emitted by bacteria for a variety of behaviors: camouflage illumination, attracting prey, avoiding predators, and finding a mate $[108,109]$. The bacteria can be found as free-living organisms in coastal waters and open sea and colonize the light organs of juvenile Leiognathidae, with approximately 40 species widespread in tropical and subtropical waters [110]. The symbiosis is initiated with a new host generation [111]. Intense multiplication leads to accumulation of a high number of bacteria, which is mostly released from the light organ into the gut tract and reaches the surrounding seawater with fecal particles. In a similar way to Aliivibrio-Euprymna symbiosis, the excess of bacteria is expelled from the light organs of fish into the seawater [112]. P. madampamensis shares many similarities with P. leiognathi, but unlike the latter, has a particular luxF gene and a broader range of hosts. This species establishes symbiosis with the cardinalfish group (Siphamia) comprising 25 species. The light organ is located in the ventral position and connected to the intestine [105]. It has been observed that some strains of $P$. mandapamensis could be correlated with water temperature [113]. The symbiosis provides fish with advantages such as attracting prey or protection against predation.

Vibrio (Aliivibrio) logei is a luminous species isolated from the light organ of the Sepiola genus, whose members live in the deeper and colder waters of the Mediterranean Sea, Japan, and the Philipines. Bacterial symbionts were first described in Sepiola atlantis by Herring et al. [114]. Later, two other species, Sepiola affinis and Sepiola robusta, were found to harbor predominantly populations of $V$. logei as light-producing symbionts [115]. It was found that these two species were colonized by a mixed population of $V$. fischeri and $V$. logei. Quantitatively, V. logei was the dominant population and ranged from $63 \%$ to $100 \%$ of total bacteria [115]. The authors hypothesized that successful colonization of Sepiola light organ by $V$. fischeri or $V$. logei might be controlled by the ambient water temperature. Therefore, animals living in the cooler waters would be predominantly colonized by $V$. logei [115]. Further experiments showed that densities of $V$. fischeri were higher when host juveniles were incubated at $26^{\circ} \mathrm{C}$, while $V$. logei reached high population densities at 18 ${ }^{\circ} \mathrm{C}$. Both $V$. fischeri and $V$. logei were able to initiate the symbiosis with juveniles when exposed to their optimal temperature. In competition experiments, colonization of the light organ occurred at $26{ }^{\circ} \mathrm{C}$ for $V$. fischeri. Proportions of the two Vibrio species were different and depended on the incubation temperature. In wild adults, abundance of $V$. fischeri and $V$. logei was variable in specimens collected at different depths and time periods, and suggested that the composition of symbiont populations depended on the temperature of surrounding waters [116].

One of the best-studied relationships between animals and luminous bacteria is the symbiosis between the Hawaiian bobtail squid (Euprymna scolopes) and $V$. fischeri. The bacteria live in a nutrient-rich habitat inside the squid's body and provide bioluminescence useful for the animal. The light provided by the bacteria acts as a camouflage mechanism by counter-illuminating the squid silhouette at night [14]. The symbiosis begins with the bacteria's recruitment by the squid from the seawater environment [117]. Bacteria do not colonize the region of the light organ directly, and must go through a series of steps required for a complex signal exchange with the host through which the squid selects $V$. fischeri $[118,119]$. The first contact between the partners takes place in the epithelial cells of the host tissues. After exposure to bacterial peptidoglican, the epitelium secrete a mucoid substance [117]. Initial interactions are nonspecific and lead to the formation of biofilms with Vibrio cells often associated with other heterotrophic bacteria [120]. The 
control of biofilm production is subjected to a complex network of signals that takes place at transcriptional and post-transcriptional levels [117]. At some point, cells of $V$. fischeri are released from the biofilm, regain a planktonic lifestyle [117], swim across the antechamber and finally reach the crypts of the light organ [121]. V. fischeri cells actively travel using the flagella and specific chemotaxis proteins $[119,122]$, but after entering the crypts they lose their flagella [122,123] as motility is no longer required. The flagellar genes are activated again before dawn, when E. scolopes expels $90 \%$ of the bacteria from its body. In the water column, V. fischeri already has functional flagella [124]. After the bacteria enter the squid's body, they induce a series of physiological and morphological changes in the light organ [125].

Light is emitted at a certain population density due to the quorum sensing (QS) control system [119,126], a mechanism of intercellular communication in response to cell density. In $V$. fischeri, QS is activated by specific inducers and regulates light production [127]. When inducers reach a specific level, they activate genes involved in light production [127,128]. Bioluminescence is the result of luciferase activity. Luciferase releases light during the oxidation of a long-chain aldehyde (R-CHO) to a fatty acid in the presence of FMNH2 [127]:

$$
\mathrm{FMNH} 2+\mathrm{O}_{2}+\mathrm{R}-\mathrm{CHO} \rightarrow \mathrm{FMN}+\mathrm{R}-\mathrm{COOH}+\mathrm{H}_{2} \mathrm{O}+\text { light. }
$$

The synthesis of $\mathrm{R}-\mathrm{CHO}$ is carried out by a complex composed of three enzymes: acyl reductase, acyl transferase, and a synthetase encoded by genes luxCDE in the lux operon [127].

\section{Vibrio spp. as Human Pathogens}

The ingestion of contaminated water, or raw or improperly cooked contaminated seafood, in particular shellfish, and wounds' exposure to water are the most common sources of Vibrio spp. infections. These infections occur in warmer waters, warmer periods and have seasonal peaks [129]. In temperate climates, most infections occur from May through October when water temperatures are warmer [130]. The species most known to cause severe infections in humans are V. cholera, V. parahaemolyticus, and V. vulnificus [131, 132]. They have high growth rates in a temperature range of $30-37^{\circ} \mathrm{C}$, and at optimum $\mathrm{pH}$ near neutral values (Table 3). Anyone can get sick from vibriosis, but there are some at-risk groups that are more likely to get an infection or have severe complications. Those with a liver disease (hepatitis B or C, cirrhosis, hemochromatosis), cancer, diabetes, HIV, or thalassemia, receiving immune-suppressing therapy, taking medication to decrease stomach acid levels, and who have recently had stomach surgery are at risk [130].

Table 3. Physiological characteristics of culturable cells of three Vibrio species important to human health, and frequently found in sea- and freshwater. PSU-practical salinity units.

\begin{tabular}{cccc}
\hline Physiologic Characteristics & V. cholerae & V. parahaemolyticus & V. vulnificus \\
\hline Temperature range $\left({ }^{\circ} \mathrm{C}\right)$ & $* 10-43$ & $5-43$ & $8-43$ \\
Optimum temperature $\left({ }^{\circ} \mathrm{C}\right)$ & $30-37$ & 37 & 37 \\
Inactivation temperature $\left({ }^{\circ} \mathrm{C}\right)$ & $>70$ & $>63$ & $>50$ \\
\hline $\mathrm{pH}$ range & $5-9.7$ & $5-11$ & $5-10$ \\
Optimum pH & 7.6 & $7.5-8.5$ & 7.8 \\
\hline Minimum water activity $\left(\mathrm{a}_{\mathrm{w}}\right)$ & 0.97 & 0.94 & 0.96 \\
$\mathrm{NaCl}(\%)$ & $<4.0$ & $0.5-8.0$ & $0.5-5.0$ \\
Salinity (PSU) & $0-20$ & $5-30$ & $8-16$ \\
\hline${ }^{*}$ Below $10{ }^{\circ} \mathrm{C}$ became VBNC $[133]$. & &
\end{tabular}

The most significant pathogenic vibrio is $V$. cholerae, an endemic species in Asia (Ganges delta, Bay of Bengal), present in both brackish and freshwaters, and the causal agent of cholera, a debilitating and frequent epidemic/pandemic disease that provokes dehydration and electrolyte loss. In the European Union/European Economic Area (EU/EEA), cholera is a rare disease. In 2019, EU countries reported 26 confirmed cases of cholera [134], 
but in developing countries, $V$. cholerae causes 1.4 to 4.3 million cases of cholera annually, resulting in 21,000-143,000 deaths per year [135]. Because of that, $V$. cholerae is the most studied vibrio. Although $V$. cholerae has more than 200 serotypes, only serotypes $\mathrm{O} 1$ and O139 are responsible for cholera epidemics while the serotypes non-O1 and non-O139 cause sporadic cholera-like infections.

The main route of contamination with cholera vibrio is through water and food, and the vectors that spread the disease are aquatic animals, such as copepods and chironomids, as well as some species of cyanobacteria [136]. The conditions that favor the appearance of cholera epidemics are generated by the improper sanitary quality of water sources [130].

After entering the human host, $V$. cholerae adheres to the intestinal epithelium and produces a specific toxin, called cholera toxin (CT) [137]. The production and accumulation of this toxin in the intestine cause intense watery diarrhea that can lead to death. The symptoms of the disease are the result of the action of several virulence genes that in $V$. cholerae are located in the ToxR regulon [138-140].

In North Europe regions, cholera (caused by $V$. cholerae serotypes $\mathrm{O} 1$ and O139) does not occur, and vibriosis is mostly caused by V. alginolyticus, V. cholerae non-O1 and non-O139, $V$. parahaemolyticus, and V. vulnificus [141]. The reported vibriosis caused by non-O1 and non-O139 V. cholera, causes sporadic cases of gastroenteritis and extraintestinal infections, such as ocular infections in immunocompromised patients or patients with chronic liver disease (Table 4). Recently, a urinary tract infection was reported involving a non-O1 $V$. cholera, also known as Vibrio albensis, in an immunocompetent 27-year-old man from Beirut. The patient denied exposure to marine water, marine animals, and eating raw seafood, and the analysis of tap water and a saltwater well recovered $V$. albensis in both samples, along with other bacteria: E. coli, Aeromonas hydrophila, Enterobacter cloacae, Pseudomonas otidis, and Shewanella putrefaciens [142].

Table 4. Examples of recent case reports (since 2011) of infections due to Vibrio and related species, patient gender, age, cause of infection, symptoms, and country.

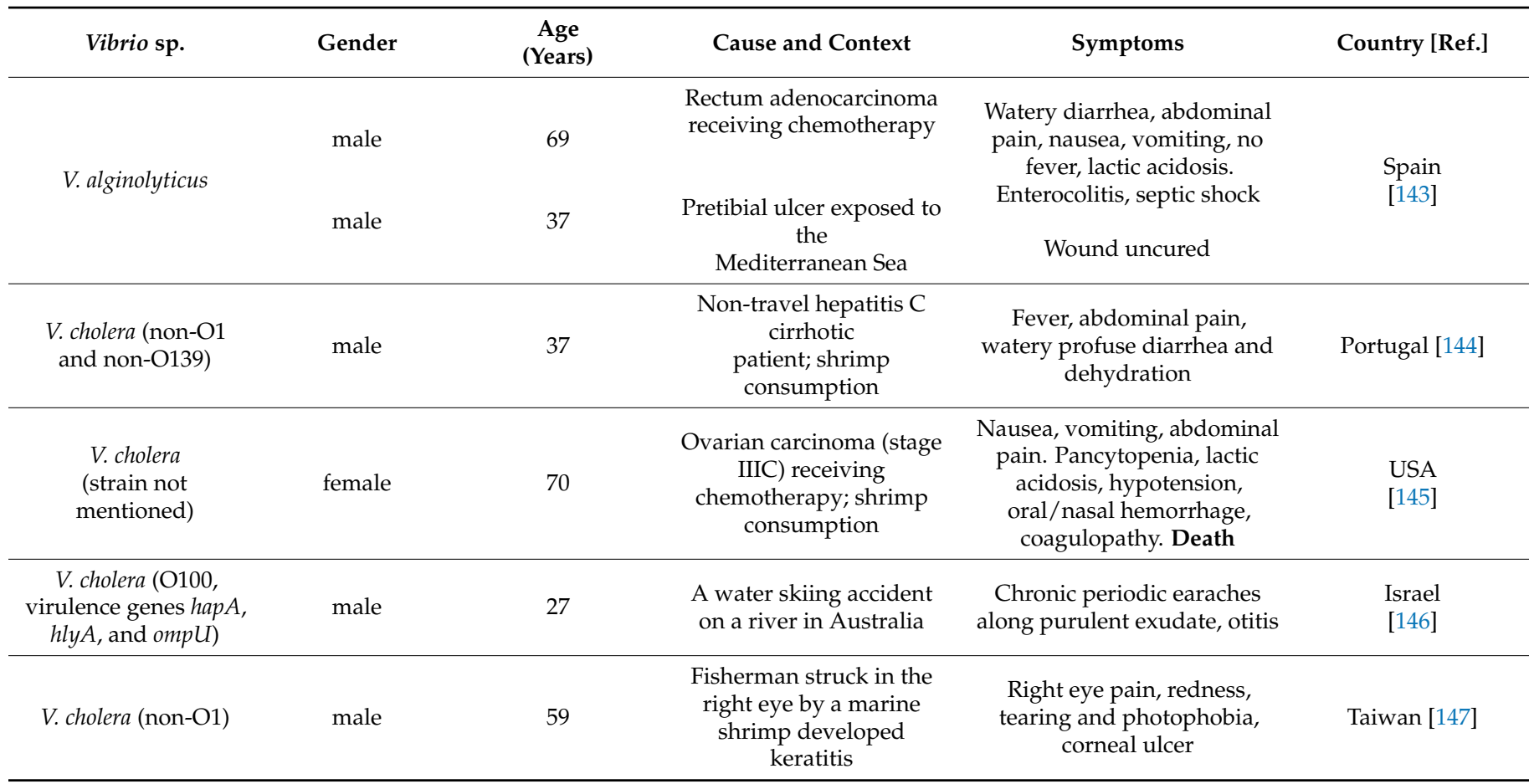


Table 4. Cont.

\begin{tabular}{|c|c|c|c|c|c|}
\hline Vibrio sp. & Gender & $\begin{array}{c}\text { Age } \\
\text { (Years) }\end{array}$ & Cause and Context & Symptoms & Country [Ref.] \\
\hline$V$. cholera (non-O1) & male & 27 & $\begin{array}{l}\text { Immunocompetent } \\
\text { patient; denied exposure } \\
\text { to marine water, marine } \\
\text { animals and eating raw } \\
\text { seafood; tap water and } \\
\text { well water contaminated }\end{array}$ & $\begin{array}{l}\text { Abdominal pain, nausea, } \\
\text { vomiting, chills and dysuria. } \\
\text { Afebrile, stable vital signs; } \\
\text { mild lower abdominal } \\
\text { tenderness. Urinary tract } \\
\text { infection }\end{array}$ & Lebanon [142] \\
\hline V. harvey & male & 26 & $\begin{array}{l}\text { Wound infection } \\
\text { following a traumatic leg } \\
\text { amputation during } \\
\text { snorkeling }\end{array}$ & $\begin{array}{l}\text { Fever, putrid infection and } \\
\text { necrosis of the subcutaneous } \\
\text { tissue and the muscles }\end{array}$ & $\begin{array}{l}\text { Spain } \\
{[148]}\end{array}$ \\
\hline $\begin{array}{c}V . \text { harvey and } P . \\
\text { damselae }\end{array}$ & male & 75 & $\begin{array}{l}\text { Fishing at a southern } \\
\text { Sydney beach. Not recall } \\
\text { any hand trauma. Treated } \\
\text { for hypertension and } \\
\text { hypercholesterolemia }\end{array}$ & $\begin{array}{l}\text { Enlarging, painful } \\
\text { hemorrhagic blister on his } \\
\text { right hand }\end{array}$ & Australia [149] \\
\hline V. metschnikovii & male & 78 & $\begin{array}{c}\text { Previous gastroenteritis } \\
\text { after shrimp } \\
\text { consumption }\end{array}$ & $\begin{array}{l}\text { Pain, swelling and redness of } \\
\text { his left dorsalis pedis, fever } \\
\text { mental confusion, severe } \\
\text { septic shock and cardiac } \\
\text { arrest. Need of mechanical } \\
\text { ventilation }\end{array}$ & Denmark [150] \\
\hline V. metschnikovii & male & 70 & $\begin{array}{l}\text { Heart failure, } \\
\text { atherosclerosis, vascular } \\
\text { prosthesis, chronic gastric } \\
\text { ulcer and kidney disease, } \\
\text { gastrointestinal bleeding }\end{array}$ & $\begin{array}{l}\text { Intestinal bleeding, } \\
\text { pseudoaneurysm of } \\
\text { aorto-bifemoral graft and } \\
\text { aorto- small intestine fistula } \\
\text { formation; hospital-acquired } \\
\text { bilateral pneumonia; } \\
\text { post-chirurgical infection }\end{array}$ & Ukraine [151] \\
\hline
\end{tabular}

\begin{tabular}{|c|c|c|c|c|c|}
\hline V. parahaemolyticus & male & 85 & $\begin{array}{c}\text { Severe valvular and } \\
\text { ischemic-hypertensive } \\
\text { cardiopathy, slight } \\
\text { chronic renal failure and } \\
\text { chronic venous leg ulcers; } \\
\text { sea beach holiday in Italy. } \\
\text { Chronic hepatitis B } \\
\text { (undiagnosed) }\end{array}$ & $\begin{array}{l}\text { Pain, limb cellulitis } \\
\text { originating from leg ulcers, } \\
\text { hypotension, acute renal } \\
\text { failure, septicemia and septic } \\
\text { shock }\end{array}$ & Switzerland [152] \\
\hline V. vulnificus & male & 39 & $\begin{array}{l}\text { Immunosuppressive } \\
\text { therapy, admitted to the } \\
\text { hospital for liver } \\
\text { transplantation }\end{array}$ & $\begin{array}{l}\text { Fever, myalgia, anuria and } \\
\text { erythematous plaques on } \\
\text { lower limbs, dyspnea and } \\
\text { respiratory distress. Death }\end{array}$ & $\begin{array}{l}\text { Brazil } \\
{[153]}\end{array}$ \\
\hline V. vulnificus & male & 46 & $\begin{array}{l}\text { History of a remote } \\
\text { Roux-en-Y gastric bypass; } \\
\text { ingestion of raw oysters }\end{array}$ & $\begin{array}{c}\text { Distress, leg soft tissue } \\
\text { necrosis, multi-organ failure, } \\
\text { mechanical ventilation, } \\
\text { disseminated intra-vascular } \\
\text { coagulopathy, large ischemic } \\
\text { stroke. Death }\end{array}$ & $\begin{array}{l}\text { USA } \\
{[154]}\end{array}$ \\
\hline V. vulnificus & male & 31 & $\begin{array}{c}\text { Chronic liver } \\
\text { disease-cirrhosis; leg } \\
\text { tattoo exposure to } \\
\text { seawater, Gulf of Mexico }\end{array}$ & $\begin{array}{l}\text { Fever, erythema in tattoo area } \\
\text { and in legs, cellulitis, septic } \\
\text { shock. Death }\end{array}$ & $\begin{array}{l}\text { USA } \\
{[155]}\end{array}$ \\
\hline P. damselae* & male & 65 & $\begin{array}{l}\text { Trauma in right arm } \\
\text { during fish cleaning; } \\
\text { arterial venous fistula } \\
\text { due blood dialysis }\end{array}$ & $\begin{array}{l}\text { Pain and edema in the arm, } \\
\text { necrotizing fasciitis }\end{array}$ & Portugal [156] \\
\hline
\end{tabular}

* Formerly V. damselae.

Like V. cholera, V. parahaemolyticus is an enteropathogenic and is responsible for gastrointestinal infections that in healthy people are mild or moderate, but in people who are at high risk (e.g., suffering diabetes, cirrhosis, cancer, or immunocompromised), it can be very serious or even fatal. V. parahaemolyticus is a ubiquitous species in the temperate and tropical coast areas and does not produce enterotoxins. This species and V. vulnificus can 
also cause infections in wounds, after exposure to contaminated water, or when handling marine food [157]. The infection can become systemic, and the affected people develop a serious medical condition with fever, hypotension, and altered mental status. Frequently, the lesions require surgical debridement or even amputation [157].

V. vulnificus is an opportunistic pathogen, frequently found in estuarine waters and can cause severe vibriosis that demands rapid diagnosis and prompt and adequate antibiotic therapy since the death rate is high (Table 4). V. vulnificus infects mostly cirrhotic patients (more than $80 \%$ ), who typically have high serum iron levels, an essential condition for a successful infection [158]. The majority of the case reports of vibriosis are in men, and in patients with chronic diseases or receiving chemotherapy. In the patients with trauma resulting from the practice of aquatic activities, or wounds exposed to seawater, the vibriosis was mild and successfully treated (Table 4). By contrast, the infections were fatal for the patients belonging to at-risk groups-those taking immunosuppressive and chemotherapies [145,153], who have had stomach surgery [154], and cirrhotic patients [155].

Other Vibrio spp., such as $V$. harveyi and V. metschnikovii, are rarely responsible or associated with human infections. $V$. harveyi is a serious pathogen of marine organisms as fish and invertebrates, and an important bacteria in seafood spoilage [159]. Lately, some case studies have been published reporting infections by $V$. harveyi in humans, after exposure to a marine environment. The infections were in a wound or an injury, and often severe, involving subcutaneous tissue and muscles necrosis, requiring tissue debridement and prolonged antibacterial therapies $[148,149,160]$; they can also appear in co-infection with $P$. damselae $[149,155]$. V. metschnikovii is a widespread bacteria in aquatic environments, and from 1981 to 2020, less than 15 reports of infections in human by this species were published, but the infections can be very debilitating [151]. V. alginolyticus is associated with ear and soft tissues infections with a good prognosis, and can be an opportunistic pathogen in fragile patients [143].

Wound infections caused by Vibrio spp. were considered rare, but there is an increasing frequency and geographic spread in reported soft tissue wound infections by $V$. vulnificus, $V$. parahaemolyticus, and $V$. alginolyticus. In the USA alone, it is estimated that vibriosis causes 80,000 illnesses and 100 deaths every year [161].

\section{Antibiotic Susceptibility in Vibrio spp.}

Most infections caused by Vibrio spp. are self-limiting and do not require clinical treatment, but antibiotics are often needed to treat severe vibriosis [162]. For cholera, antibiotics are not considered to be a life-saving treatment. If the patient hydration status is maintained they will recover without antibiotics, although the duration of illness doubles [163]. Because cholera generally occurs in areas with deficient health services, when antimicrobial resistance (AMR) occurs, more human and therapeutic resources are needed which, if not met, could result in more deaths [163]. Currently, in the treatment of cholera, azithromycin (a macrolide), doxycycline (a tetracycline), or ciprofloxacin (a quinolone) are used [164], but the arsenal of antibiotics against this disease has been decreasing considerably [165]. Bacteremia due to $V$. cholerae non-O1 and non-O139 strains are treated with third-generation cephalosporins and quinolones $[142,144,146]$.

V. parahaemolyticus and V. vulnificus are important species in public health, causing infections that are most associated with seafood [166]. Currently, doxycycline and a thirdgeneration cephalosporin are recommended for $V$. vulnificus as an initial treatment regimen, whereas doxycycline or quinolone are administered for V. parahaemolyticus [164]. V. vulnificus infections often have a fatal outcome, even when the recommended antibiotic therapy is applied early [155]. Frequently, infections caused by $V$. vulnificus rapidly deteriorate the patient's condition and end in death a few hours or days after the onset of infection $[153,154]$.

In general, Vibrio spp. are susceptible to most antimicrobials used to treat animal or human infections, but several antibiotic-resistant strains of Vibrio spp. have been reported [166]. In recently reported human vibriosis (Table 4), a severe otitis caused by $V$. cholera $\mathrm{O} 100$ was successfully treated with ciprofloxacin. The strain was suscepti- 
ble to mostly the tested antibiotics (amoxicillin/clavulanic acid), cefuroxime, trimethoprim/sulfamethoxazole), gentamicin, and ciprofloxacin), but resistant to polymyxin B sulfate [146]. A urinary infection caused by a non-O1 Vibrio cholerae strain was treated with ciprofloxacin. The strain was susceptible to all $(n=22)$ the tested antimicrobials [142]. A wound infected by Vibrio harveyi was first treated with ampicillin, which was rapidly switched to ceftriaxone and ciprofloxacin. This approach, along with surgical debridement, controlled the infection and the patient was discharged [148].

Resistance to antibiotics was also reported in other Vibrio spp. strains. A V. metschnikovii strain was resistant to ampicillin, but susceptible to meropenem and piperacillin/ tazobactam [150]. Another V. metschnikovii strain, tested against 47 antibiotics, was resistant to 17, among them cefotaxime and co-trimoxazole [151]. Two strains of $V$. alginolyticus were reported resistant: one to ampicillin (and susceptible to amoxicillin/clavulanic acid, ciprofloxacin, and imipenem) and the other to penicillin and ampicillin (and susceptible to cefotaxime, ceftazidime, ciprofloxacin, and tetracycline) [143]. In a hand infected by both $P$. damselae and $V$. harveyi, the patient was first treated with doxycycline and cefazolin. After surgical debridement, the treatment was completed with 7 days of doxycycline. Both strains were susceptible to doxycycline, ceftriaxone, ciprofloxacin, cefepime, and ticarcillinclavulanic acid. P. damselae was also ampicillin susceptible, contrary to V. harveyi [149].

The increasing antibiotic resistance in many Vibrio spp. associated with human infections is due the high probability of horizontal gene transfer between virulent and non-virulent strains [167]. Aquatic environments and environmental multidrug resistant (MDR) strains could play a role in the spread of antibiotic-resistant genes [168].

In 2013, in 62 strains of $V$. cholera isolated from ship ballast tanks (USA), the antibiotic resistance was almost restricted to ampicillin, and MDR was uncommon [169]. Recently, more than $99 \%$ of $443 \mathrm{~V}$. cholerae isolates from the Bay of Bengal (India) were MDR, and their genome was enriched with acquired genetic elements [170].

In a large survey of virulence and antibiotic resistance in environmental $V$. parahaemolyticus strains along the Atlantic coast of Georgia and South Carolina, 350 strains of $V$. parahaemolyticus were isolated and tested against 24 antibiotics. Almost $25 \%$ of the isolates demonstrated resistance to 10 or more agents, including amoxicillin, ampicillin, apramycin, cephalothin, penicillin, streptomycin, amikacin, cephalothin, gentamicin, nalidixic acid, and trimethoprim. All isolates were susceptible to ceftriaxone, chloramphenicol, ciprofloxacin, imipenem, ofloxacin, nitrofurantoin, meropenem, oxytetracycline, and tetracycline [168].

$V$. vulnificus $(\mathrm{n}=120)$ and $V$. parahaemolyticus $(\mathrm{n}=77)$ recovered from Chesapeake Bay and Maryland Coastal Bays (USA) surface water were tested against 26 antimicrobials. $V$. vulnificus isolates were susceptible to 14 of the 26 antibiotics tested, including the ones recommended by the CDC for the treatment of $V$. vulnificus infections, such as tetracyclines, quinolones, and folate pathway inhibitors. All $V$. parahaemolyticus isolates were susceptible to 11 of the 26 tested antibiotics and four (carbapenems, tetracyclines, quinolones, and folate pathway inhibitors) of the eight tested antimicrobial classes. V. parahaemolyticus isolates exhibited a high percentage of resistance against penicillin $(68 \%)$ and ampicillin (53\%) [171].

In South Africa, 118 Vibrio isolates recovered from different freshwater sources in rural environments, comprising $V$. fluvialis $(\mathrm{n}=41), V$. mimicus $(\mathrm{n}=40)$, and $V$. vulnificus $(\mathrm{n}=37)$, were tested for their susceptibility to antibiotics. With the exceptions of imipenem, meropenem, and ciprofloxacin, most isolates exhibited more than $50 \%$ resistance to antibiotics. All isolates were resistant to polymyxin B and azithromycin, and $16.1 \%$ were resistant to ciprofloxacin. The multiple antibiotic resistance index (MARI) ranged from 0.3 to 0.8 with most isolates showing MARI of 0.8 [172].

From the waters of the Jacarepaguá lagoon system, in Rio de Janeiro, Brazil, a MDR $V$. parahaemolyticus strain JPA1 was isolated. The strain was tested against 16 antibiotics and displayed resistance to eight of them, seven $\beta$-lactams and one a polymyxin, but was susceptible to all aminoglycosides, tigecycline, and ciprofloxacin [173]. Despite the $V$. parahaemolyticus strain JPA1 being non-virulent to humans, it encodes several genes 
that have been involved in several mechanisms of resistance against different classes of antibiotics, such as antibiotic efflux, regulation of efflux, antibiotic inactivation, and target replacement [173].

The prevalence of antimicrobial resistance was assessed in 70 Vibrio strains isolated from diseased cultivated marine fish in Guangdong and Hainan provinces, South China. Most of the isolates belonged to V. harveyi (27), V. vulnificus (11), and V. alginolyticus (10), and showed high resistance to vancomycin (95.71\%), amoxicillin (68.57\%), midecamycin $(67.14 \%)$, and furazolidone (55.71\%), and high susceptibility to erythromycin, trimethoprimsulfamethoxazole, doxycycline, and chloramphenicol. MARI ranged from 0.00 to 0.60 [174].

The prevalence of Vibrio spp. in groupers (Epinephelus spp.) in nine farms located in Malaysia was high (72\%), and the most prevalent species were Vibrio communis (28\%), $V$. parahaemolyticus (25\%), V. alginolyticus (19\%), and V. vulnificus (14\%). Of 380 Vibrio strains, $97 \%$ were resistant to at least one antibiotic. The majority were highly resistant to penicillin $\mathrm{G}$ and ampicillin (82\%), and susceptible to tetracycline (84\%), streptomycin (67\%), and vancomycin (34\%). MDR was high: 98 (27\%) isolates were resistant to four, $67(18 \%)$ to five, $10(3 \%)$ to six, and $1(0.3 \%)$ to 7 antibiotics [175].

A recent systematic review on the abundance of AMR bacteria found in aquaculture environments (Aeromonas spp., Edwardsiella spp., Flavobacterium columnare, Lactococcus spp., Streptococcus spp., Vibrio spp., and Yersinia spp.) calculated MARI for 40 countries, which accounted for $93 \%$ of global animal aquaculture production. Twenty-eight countries displayed MAR indices higher than 0.2 , which indicates a high-risk antibiotic contamination. A strong positive correlation $(\mathrm{r}=0.58, p<0.001)$ was also found between human clinical MARI and aquaculture-derived MARI [176].

\section{Risks Related to Vibrio spp.}

Vibrio spp. are ubiquitous in aquatic environments, especially marine ones, playing many roles as scavengers, symbionts, and pathogens [21]. Among the pathogenic vibrios, $V$. parahaemolyticus, $V$. cholera, and $V$. vulnificus are the most important from a foodborne infection point of view [11]. From this three species, $V$. cholerae and $V$. parahaemolyticus have the ability for pandemic expansion threatening the global public health [129]. Related to marine, brackish, and freshwater ecosystems, the infections caused by vibrios are gaining importance and, during the last decade, several worldwide organizations related to health released information and alerts on the increase in the number of infections caused by vibrios, the risk groups, and the most exposed activities and professions [177-180].

In the USA, vibriosis infections are reported via the Cholera and Other Vibrio Illness Surveillance (COVIS) system. COVIS was initiated in 1989 by CDC, FDA, and Alabama, Florida, Louisiana, and Texas, four Gulf Coast states. By the early 2000s, almost all states were voluntarily reporting [180]. From 1988 to 2012, the reported infections by V. alginolyticus increased 12-fold, and most of them were from coastal states (96\%) and involved water activities (86\%) [181]. The number may be underestimated because Vibrio bacteria are not easily identified with routine testing, and many cases may not be reported. The US Vibrio incidence in the period from 2016-2018 and in 2019 increased significantly (79\%) [180]. The CDC estimated that around 80,000 vibriosis infections occur each year in the USA, of which 52,000 result from consuming contaminated food. Most patients have mild symptoms and recover after about 3 days, but of those with $\mathrm{V}$. vulnificus infection 20\% die [180].

The Korea Centers for Disease Control and Prevention (KCDC) reported an increase in $V$. vulnificus infections in the first eight months of 2020, more than double the cases from the same period in 2019 [182].

In Europe, the number of infections related to these pathogens has also increased since 1990 [177,179]. In a joint report of the European Food Safety Authority (EFSA) and the European Centre for Disease Prevention and Control (ECDC), Vibrio was identified in four small foodborne outbreaks in France and in Italy. The agent was identified as $V$. parahaemolyticus in all French outbreaks, while no information was available for the others. For Vibrio, of 326 food samples in total from Bulgaria, the Netherlands, and Sweden, 32 
were positive (9.8\%). These positive results were from raw fish, shrimps, and lobsters from border inspection activities in the three countries [183].

There are several hypotheses or explanations for the steady increase of infections by Vibrio spp., both in industrialized and developing countries [11,184]. Due to the worldwide increase in seafood consumption, there has been an incremental increase in the global production of seafood (mainly fish, crustaceans, and mollusks) by aquaculture and in the capture of wild populations. In 2018, and in millions of tons (Mt), the global capture of marine fish reached $94.4 \mathrm{Mt}$ (marine 84.4), followed by fish produced in aquaculture $82.1 \mathrm{Mt}$ (marine 30.89), aquatic algae (mostly seaweed) $32.4 \mathrm{Mt}$, mollusks (mainly bivalves) 17.7 $\mathrm{Mt}$, and crustaceans $9.4 \mathrm{Mt}$ [185]. The rising contamination of sea water including from inadequately treated sewage effluent, and the increase in the world trade of seafood along with the increase in its consumption in raw or undercooked conditions, have resulted in an increase in infections caused by Vibrio $[30,141,184]$. In sub-Saharan countries, the contamination of drinking and recreational water and the consumption of inadequately cooked aquatic food products remain a threat to public health $[57,184]$. In that part of the world, and despite cholera epidemics being frequent, there is a lack of knowledge about the microbial quality of water sources. In a survey on urban water reservoirs $(n=39)$ in Burkina Faso, $14.78 \%$ of them had V. cholera non-O1 and non-O139 [186].

In parallel, the continuous increase in recreational activities on, in, and along aquatic bodies, such as sport fishing, boating, bathing, diving, snorkeling, surfing, animal watching, and sailing, which positively contribute to human well-being [187], can also put at risk their practitioners. The growth of economic activities such as tourism and maritime traffic also affects Vibrio spp. abundance and diversity all over the globe. The water from BWs is a known sources of many organisms, among them pathogenic bacteria such as Vibrio spp., including the serotypes of $V$. cholerae O1 [36,169], O59, and 139 [169]. Along with the high concentrations of pathogenic strains, resistance to antimicrobials is often present in an expressive way [169].

The increase in the number of infections by Vibrio species has also been reported in species farmed in aquaculture. Outbreaks with significant mortality of the farmed Pacific oyster (Crassostrea gigas) have been reported in France and other European countries from 2008 onwards, and some others were reported in 2010-2011 from Australia and New Zealand. V. aestuarianus subsp. francensis has been associated with those events [188]. In an aquaculture facility for Saccharina latissima growth for human consumption located in Northeast USA, Escherichia coli O157:H7, Salmonella enterica ser. typhimurium, V. parahaemolyticus, and $V$. alginolyticus were found in both kelp and water samples during the winter. Despite the low levels, the frequency of detection poses a risk of foodborne pathogens, so best management practices are recommended to control microbial growth during kelp harvest and processing [63]. One of the most promising fish species for the diversification of aquaculture in the Mediterranean is the amberjack (Seriola dumerili), but its production expansion is failing due to its pathogens, among them $V$. harveyi and P. damselae [189].

In addition, the risks of the Vibrio spp. to environmental, animal, and human health may be enhanced by climate change, especially the ocean warming [190]. Recent data support the hypothesis that climate change, along with environmental pollution, epidemiological, demographic, and behavioral factors, is increasing the geographical spread as well the frequency of vibriosis [21,191]. In the period between 1962 and 2004, the temperature increased $1.13^{\circ} \mathrm{C}$ in the North Sea at Helgoland [192]. Recently and in the same region was reported for the first time the serotype V. cholerae O139 [193].

The temperature rising can contribute, directly or indirectly, to changes in geographic distribution of Vibrio spp., community composition, species dominance, and even the dominance of virulence genes $[37,42,43,129,193,194]$. Over a 14 -month period, V. parahaemolyticus, $V$. vulnificus, and $V$. cholerae increased their abundance, measured by MPN-PCR, during the summer months in the German bight. The environmental factors that mostly explained the variations were temperature and nitrites; the virulence factors of the three species varied in 
time and space, and in $V$. cholerae more than four virulence-associated genes were detected at temperatures above $16.8^{\circ} \mathrm{C}$ [193].

In aquatic animals such as fish, the water temperature, in addition to affecting the prevalence of virulence factors, can also affect the quality of the host's immune response to infection, due to cumulative stress responses [195]. In mussels, high temperature may reduce the ability to eliminate bacteria in hemolymph [196]. Isolates of $V$. splendidus and $V$. aestuarianus were moderately pathogenic for mussels in intramuscular infections and bath infections, and mortalities only occurred when animals were infected with a high bacterial concentration at $25^{\circ} \mathrm{C}$ and in hypoxia [81].

Vibrio spp. are free-living inhabitants of marine coastal waters, brackish, and inland aquatic bodies, and their presence does not indicate fecal contamination. The monitoring of water microbial quality is based on fecal indicator bacteria (FIB), which may be below the detection limit when Vibrio or other high-risk bacterial groups are present [38]. Consequently, prevention efforts should target waterborne transmission in coastal areas, and provide education of health personnel, to promote a rapid diagnosis and prevent clinical complications caused by Vibrio spp. [181]. In addition, the ability of vibrios to adapt to many environmental conditions and niches that can be polluted or/and under pressure of climate change supports the need for further research to understand their ecological role, dissemination, and risks in freshwater ecosystems [23,184].

All the players involved in water and water resources exploration should considerer collaborative networks, and a multiparametric approach of microbial indicators of quality and pollution in water systems. The research network VibrioNet proposes study of the non-cholera vibrio pathogenic species ( $V$. parahaemolyticus, $V$. vulnificus, $V$. cholerae non-O1, non-O139, V. alginolyticus) in marine environments and in seafood consumed by humans, and their risks in central Europe [141].

Sampling processing, culture and molecular detection methods to identify microorganisms in complex environmental samples, and water quality standards need to be updated and harmonized for more accurate and timely detection of health hazards [197]. We need a better understanding of the ecology of non-enteric microorganisms, such as vibrios, and their environmental significance, and to establish non-fecal indicators and sentinels, the ecology of the virulent strains, and their antibiotic susceptibility profiles to anticipate risks and prepare our response.

Author Contributions: Conceptualization, F.A. and A.S.; validation, F.A., A.S., V.S. and P.P.; investigation, F.A., V.S. and A.S.; writing—original draft preparation, F.A., V.S. and A.S.; writing—review and editing, F.A., A.S. and P.P.; supervision, F.A. and A.S. All authors have read and agreed to the published version of the manuscript.

Funding: This research was supported by National Funds by FCT-Portuguese Foundation for Science and Technology, through the projects CITAB (UIDB/04033/2020), UIDB/CVT/00772/2020, and the Associate Laboratory for Green Chemistry-LAQV (UIDB/50006/2020 and UIDP/50006/2020). Vanessa Silva is grateful to FCT (Fundação para a Ciência e a Tecnologia) for financial support through the Ph.D. grant SFRH/BD/137947/2018.

Institutional Review Board Statement: Not applicable.

Data Availability Statement: Project data publicly available in the Forest Research Institute library.

Conflicts of Interest: The authors declare no conflict of interest. The funders had no role in the design of the study; in the collection, analyses, or interpretation of data; in the writing of the manuscript, or in the decision to publish the results.

\section{References}

1. Wright, A.C.; Hill, R.T.; Johnson, J.A.; Roghman, M.C.; Colwell, R.R.; Morris, J.G. Distribution of Vibrio vulnificus in the Chesapeake Bay. Appl. Environ. Microbiol. 1996, 62, 717-724. [CrossRef]

2. Thompson, J.R.; Marcelino, L.A.; Polz, M.F. Diversity, sources and detection of human bacterial pathogens in the marine environment. In Oceans and Health: Pathogens in the Marine Environment; Belkin, S., Colwell, R.R., Eds.; Springer: New York, NY, USA, 2005; pp. 29-68. [CrossRef] 
3. Barbieri, E.; Falzano, L.; Fiorentini, C.; Pianetti, A.; Baffone, W.; Fabbri, A.; Matarrese, P.; Casiere, A.; Katouli, M.; Kuhn, I.; et al. Occurrence, diversity, and pathogenicity of halophilic Vibrio spp. and non-O1 Vibrio cholerae from estuarine waters along the Italian Adriatic coast. Appl. Environ. Microbiol. 1999, 65, 2748-2753. [CrossRef]

4. Denner, E.B.M.; Vybiral, D.; Fischer, U.R.; Velimirov, B.; Busse, H.J. Vibrio calviensis sp. nov., a halophilic, facultatively oligotrophic 0.2 micron-filterable marine bacterium. Int. J. Syst. Evol. Microbiol. 2002, 52, 549-553. [CrossRef]

5. Heidelberg, J.F.; Heidelberg, K.B.; Colwell, R.R. Seasonality of Chesapeake Bay bacterioplankton species. Appl. Environ. Microbiol. 2002, 68, 5488-5497. [CrossRef]

6. Vezzulli, L.; Pezzati, E.; Moreno, M.; Fabiano, M.; Pane, L.; Pruzzo, C.; VibrioSea Consortium. Benthic ecology of Vibrio spp. and pathogenic Vibrio species in a coastal Mediterranean environment (La Spezia Gulf, Italy). Microb. Ecol. 2009, 58, 808-818. [CrossRef]

7. Baumann, P.; Furniss, A.L.; Lee, J.V. Genus, I. Vibrio. In Bergey's Manual of Systematic Bacteriology, 1st ed.; Krieg, N.R., Holt, J.G., Eds.; The Williams \& Wilkins Co.: Baltimore, MA, USA, 1984; Volume 1, pp. 518-538.

8. Genus Vibrio. Available online: www.bacterio.net/vibrio.html (accessed on 4 November 2021).

9. Chakraborty, S.; Nair, G.B.; Shinoda, S. Pathogenic vibrios in the natural aquatic environment. Rev. Environ. Health 1997, 12, 63-80. [CrossRef]

10. Pruzzo, C.; Huq, A.; Colwell, R.R.; Donelli, G. Pathogenic Vibrio species in the marine and estuarine environment. In Oceans and Health: Pathogens in the Marine Environment; Belkin, S., Colwell, R.R., Eds.; Springer: New York, NY, USA, 2005 ; pp. 217-252. [CrossRef]

11. Nair, G.B.; Faruque, S.M.; Sack, D.A. 13-Vibrios. In Emerging Foodborne Pathogens; Motarjemi, Y., Adams, M., Eds.; Woodhead Publishing Limited: Cambridge, UK, 2006; pp. 332-372. [CrossRef]

12. Jones, J.L. Vibrio: Introduction, Including Vibrio parahaemolyticus, Vibrio vulnificus, and other Vibrio species. In Encyclopedia of Food Microbiology, 2nd ed.; Batt, C.A., Tortorello, M.L., Eds.; Academic Press: London, UK, 2014; pp. 691-698.

13. Farmer, J.J., III; Michael Janda, J.; Brenner, F.W.; Cameron, D.N.; Birkhead, K.M. Vibrio . In Bergey's Manual of Systematics of Archaea and Bacteria; The Editorial Board; In Association with Bergey's Manual Trust; John Wiley \& Sons, Inc.: Hoboken, NJ, USA, 2015; pp. 1-79.

14. Pacini, F. Osservazione microscopiche e deduzioni patologiche sul Cholera Asiatico. Gaz Med. Ital. Toscana Firenze 1854, 6, 405-412.

15. Bally, M.; Garrabou, J. Thermodependent bacterial pathogens and mass mortalities in temperate benthic communities: A new case of emerging disease linked to climate change. Glob. Chang. Biol. 2007, 13, 2078-2088. [CrossRef]

16. Heidelberg, J.F.; Eisen, J.A.; Nelson, W.C.; Clayton, R.A.; Gwinn, M.L.; Dodson, R.J.; Haft, D.H.; Hickey, E.K.; Peterson, J.D.; Umayam, L.; et al. DNA sequence of both chromosomes of the cholera pathogen Vibrio cholera. Nature 2000, 406, 477-483. [CrossRef]

17. Thompson, F.L.; Gevers, D.; Thompson, C.C.; Dawyndt, P.; Hoste, B.; Munn, C.B.; Swings, J. Phylogeny and molecular identification of vibrios on the basis of multilocus sequence analysis. Appl. Environ. Microbiol. 2005, 71, 5107-5115. [CrossRef]

18. Sawabe, T.; Kita-Tsukamoto, K.; Thompson, F.L. Inferring the evolutionary history of vibrios by means of multilocus sequence analysis. J. Bacteriol. 2007, 189, 7932-7936. [CrossRef]

19. Al-Saari, N.; Gao, F.; Rohul, A.A.K.M.; Sato, K.; Sato, K.; Mino, S.; Suda, W.; Oshima, K.; Hattori, M.; Ohkuma, M.; et al. Advanced microbial taxonomy combined with genome-based approaches reveals that Vibrio astriarenae sp. nov., an agarolytic marine bacterium, forms a new clade in Vibrionaceae. PLoS ONE 2015, 10, e0136279. [CrossRef]

20. Farmer, J.J., III; Hickman-Brenner, F.W. The Genera Vibrio and Photobacterium. In The Prokaryotes; Dworkin, M., Falkow, S., Rosenberg, E., Schleifer, K.H., Stackebrandt, E., Eds.; Springer: New York, NY, USA, 2006; pp. 508-563. [CrossRef]

21. Grimes, D.J. The vibrios: Scavengers, symbionts, and pathogens from the sea. Microb. Ecol. 2020, 80, 501-506. [CrossRef]

22. Baker-Austin, C.; Trinanes, J.; Martinez-Urtaza, J. The new tools revolutionizing Vibrio science. Environ. Microbiol. 2020, 22, 4096-4100. [CrossRef]

23. Abioye, O.E.; Osunla, A.C.; Okoh, A.I. Molecular detection and distribution of six medically important Vibrio spp. in selected freshwater and brackish water resources in Eastern Cape Province, South Africa. Front. Microbiol. 2021, 12, 617703. [CrossRef]

24. Percival, S.L.; Williams, D.W. Chapter Twelve-Vibrio. In Microbiology of Waterborne Diseases: Microbiological Aspects and Risks, 2nd ed.; Percival, S., Yates, M.V., Williams, D.W., Chalmers, R.M., Gray, N.F., Eds.; Academic Press: Amsterdam, The Netherlands; Boston, MA, USA, 2014; pp. 237-248.

25. McCarter, L. The multiple identities of Vibrio parahaemolyticus. J. Mol. Microbiol. Biotechnol. 1999, 1, 51-57.

26. Lipp, E.K.; Huq, A.; Colwell, R.R. Effects of global climate on infectious disease: The cholera model. Clin. Microbiol. Rev. 2002, 15, 757-770. [CrossRef]

27. Ruby, E.G. Lessons from a cooperative, bacterial-animal association: The Vibrio fischeri-Euprymna scolopes light organ symbiosis. Annu. Rev. Microbiol. 1996, 50, 591-624. [CrossRef]

28. Grau, B.L.; Henk, M.C.; Pettis, G.S. High-frequency phase variation of Vibrio vulnificus 1003: Isolation and characterization of a rugose phenotypic variant. J. Bacteriol. 2005, 187, 2519-2525. [CrossRef]

29. Li, L.; Mendis, N.; Trigui, H.; Oliver, J.D.; Faucher, S.P. The importance of the viable but non-culturable state in human bacterial pathogens. Front. Microbiol. 2014, 5, 258. [CrossRef] 
30. Bonnin-Jusserand, M.; Copin, S.; Le Bris, C.; Brauge, T.; Gay, M.; Brisabois, A.; Grard, T.; Midelet-Bourdin, G. Vibrio species involved in seafood-borne outbreaks (Vibrio cholerae, V. parahaemolyticus and V. vulnificus): Review of microbiological versus recent molecular detection methods in seafood products. Crit. Rev. Food Sci. Nutr. 2019, 59, 597-610. [CrossRef]

31. Thompson, J.R.; Polz, M.F. Dynamics of Vibrio populations and their role in environmental nutrient cycling. In The Biology of Vibrios; Thompson, F.L., Austin, B., Swings, J., Eds.; American Society for Microbiology: Washington, DC, USA, 2006 ; pp. 190-203.

32. Cottrell, M.T.; Kirchman, D.L. Contribution of major bacterial groups to bacterial biomass production (thymidine and leucine incorporation) in the Delaware estuary. Limnol. Oceanogr. 2003, 48, 168-178. [CrossRef]

33. Beardsley, C.; Pernthaler, J.; Wosniok, W.; Amann, R. Are readily culturable bacteria in coastal North Sea waters suppressed by selective grazing mortality? Appl. Environ. Microbiol. 2003, 69, 2624-2630. [CrossRef]

34. Oberbeckmann, S.; Fuchs, B.M.; Meiners, M.; Wichels, A.; Wiltshire, K.H.; Gerdts, G. Seasonal dynamics and modeling of a Vibrio community in coastal waters of the North Sea. Microb. Ecol. 2012, 63, 543-551. [CrossRef]

35. Böer, S.I.; Heinemeyer, E.A.; Luden, K.; Erler, R.; Gerdts, G.; Janssen, F.; Brennholt, N. Temporal and spatial distribution patterns of potentially pathogenic Vibrio spp. at recreational beaches of the German North Sea. Microb. Ecol. 2013, 65, 1052-1067. [CrossRef]

36. Rivera, I.N.G.; Souza, K.M.C.; Souza, C.P.; Lopes, R.M. Free-living and plankton-associated vibrios: Assessment in ballast water, harbor areas, and coastal ecosystems in Brazil. Front. Microbiol. 2013, 3, 443. [CrossRef]

37. Di, D.Y.W.; Lee, A.; Jang, J.; Han, D.; Hura, H.-G. Season-specific occurrence of potentially pathogenic Vibrio spp. on the Southern Coast of South Korea. Appl. Environ. Microbiol. 2017, 83, e02680-16. [CrossRef]

38. Gyraite, G.; Kataržytè, M.; Overlingè, D.; Vaičiūtè, D.; Jonikaitè, E.; Schernewski, G. Skip the dip-Avoid the risk? Integrated microbiological water quality assessment in the South-Eastern Baltic Sea coastal waters. Water 2020, 12, 3146. [CrossRef]

39. Amirmozafari, N.; Forohesh, H.; Halakoo, A. Occurrence of pathogenic vibrios in coastal areas of Golestan Province in Iran. Arch. Razi Ins. 2005, 60, 33-44.

40. Machado, A.; Bordalo, A.A. Detection and quantification of Vibrio cholerae, Vibrio parahaemolyticus, and Vibrio vulnificus in coastal waters of Guinea-Bissau (West Africa). EcoHealth 2016, 13, 339-349. [CrossRef]

41. Costa, R.A.; Silva, G.C.; Peixoto, J.R.O.; Vieira, G.H.F.; Vieira, R.H.S.F. Quantification and distribution of Vibrio species in water from an estuary in Ceará-Brazil impacted by shrimp farming. Braz. J. Oceanogr. 2010, 8, 183-188. [CrossRef]

42. Greenfield, D.I.; Moore, J.G.; Stewart, J.R.; Hilborn, E.D.; George, B.J.; Li, Q.; Dickerson, J.; Keppler, C.K.; Sandifer, P.A. Temporal and environmental factors driving Vibrio vulnificus and $V$. parahaemolyticus populations and their associations with harmful algal blooms in South Carolina detention ponds and receiving tidal creeks. Geohealth 2017, 1, 306-317. [CrossRef]

43. Jesser, K.J.; Noble, R.T. Vibrio ecology in the Neuse River Estuary, North Carolina, characterized by Next-Generation Amplicon Sequencing of the gene encoding Heat Shock Protein 60 (hsp60). Appl. Environ. Microbiol. 2018, 84, e00333-18. [CrossRef]

44. Kokashvili, T.; Whitehouse, C.A.; Tskhvediani, A.; Grim, C.J.; Elbakidze, T.; Mitaishvili, N.; Janelidze, N.; Jaiani, E.; Haley, B.J.; Lashkhi, N.; et al. Occurrence and diversity of clinically important Vibrio species in the aquatic environment of Georgia. Front. Public Health 2015, 3, 232. [CrossRef]

45. Lipp, E.K.; Rodriguez-Palacios, C.; Rose, J.B. Occurrence and distribution of the human pathogen Vibrio vulnificus in a subtropical Gulf of Mexico estuary. Hydrobiologia 2001, 460, 165-173. [CrossRef]

46. Griffitt, K.J.; Grimes, D.J. Abundance and distribution of Vibrio cholerae, V. parahaemolyticus, and V. vulnificus following a major freshwater intrusion into the Mississippi Sound. Microbial Ecol. 2013, 65, 578-583. [CrossRef]

47. Sobrinho, P.S.C.; Destro, M.T.; Franco, B.D.G.M.; Landgraf, M. Correlation between environmental factors and prevalence of Vibrio parahaemolyticus in oysters harvested in the southern coastal area of Sao Paulo state, Brazil. Appl. Environ. Microbiol. 2010, 76, 1290-1293. [CrossRef]

48. Nilsson, W.B.; Paranjpye, R.N.; Hamel, O.S.; Hard, C.; Strom, M.S. Vibrio parahaemolyticus risk assessment in the Pacific Northwest: It's not what's in the water. FEMS Microbiol. Ecol. 2019, 95, fiz027. [CrossRef]

49. La Rosa, T.; Mirto, S.; Mazzola, A.; Danovaro, R. Differential responses of benthic microbes and meiofauna to fish-farm disturbance in coastal sediments. Environ. Pollut. 2001, 112, 427-434. [CrossRef]

50. Cabral, J.P.S. Water microbiology. Bacterial pathogens and water. Int. J. Environ. Res. Public Health 2010, 7, 3657-3703. [CrossRef]

51. Dufour, A.; Bartram, J.; Bos, R.; Gannon, V. Animal waste, water quality and human health. Water Intell Online 2013, 12, 1-10. [CrossRef]

52. Delahoy, M.J.; Wodnik, B.; McAliley, L.; Penakalapati, G.; Swarthout, J.; Freeman, M.C.; Levy, K. Pathogens transmitted in animal feces in low- and middle-income countries. Int. J. Hyg. Environ. Health 2018, 221, 661-676. [CrossRef]

53. Gardade, L.; Khandeparker, L. Spatio-temporal variations in pathogenic bacteria in the surface sediments of the Zuari estuary, Goa, India. Curr. Sci. 2017, 113, 1729-1738. [CrossRef]

54. Shibata, T.; Solo-Gabriele, H.M.; Fleming, L.E.; Elmir, S. Monitoring marine recreational water quality using multiple microbial indicators in an urban tropical environment. Water Res. 2004, 38, 3119-3131. [CrossRef]

55. Ghinsberg, R.C.; Drasinover, V.; Sheinberg, Y.; Nitzan, Y. Seasonal distribution of Aeromonas hydrophila and Vibrio species in Mediterranean coastal water and beaches: A possible health hazard. Biomed. Lett. 1995, 51, 151-159.

56. Elmanama, A.A.; Fahd, M.I.; Afifi, S.; Abdallah, S.; Bahr, S. Microbiological beach sand quality in Gaza Strip in comparison to seawater quality. Environ. Res. 2005, 99, 1-10. [CrossRef]

57. Oyelade, A.; Fagade, O.; Sanuth, H.; Anjolaiya, L.; Nwadike, B. Microbiological quality of some recreational beaches along the shoreline of Lagos State, Nigeria. J. Environ. Earth Sci. 2018, 8, 61-76. 
58. McDougald, D.; Kjelleberg, S. Adaptive responses of Vibrios. In The Biology of Vibrios; Thompson, F.L., Austin, B., Swings, J., Eds.; American Society for Microbiology: Washington, DC, USA, 2006; pp. 133-155.

59. Rehnstam-Holm, A.S.; Godhe, A.; Härnström, K.; Raghunath, P.; Saravanan, V.; Collin, B.; Karunasagar, I. Association between phytoplankton and Vibrio spp. along the southwest coast of India: A mesocosm experiment. Aquat. Microb. Ecol. 2010, 58, 127-139. [CrossRef]

60. Hsieh, J.L.; Fries, J.S.; Noble, R.T. Vibrio and phytoplankton dynamics during the summer of 2004 in a eutrophying estuary. Ecol. Appl. 2007, 17, S102-S109. [CrossRef]

61. Karl, D.M. Microbial oceanography: Paradigms, processes and promise. Nat. Rev. Microbiol. 2007, 5, 759-769. [CrossRef]

62. Titlyanov, E.A.; Titlyanova, T.V.; Li, X.; Huang, H. Chapter 2-Marine Plants of Coral Reefs. In Coral Reef Marine Plants of Hainan Island; Academic Press: Cambridge, MA, USA; Elsevier: Amsterdam, The Netherlands, 2017; pp. 5-39.

63. Barberi, O.N.; Byron, C.J.; Burkholder, K.M.; Gelais, A.T.S.; Williams, A.K. Assessment of bacterial pathogens on edible macroalgae in coastal waters. J. Appl. Phycol. 2020, 32, 683-696. [CrossRef]

64. Carli, A.; Pane, L.; Casareto, L.; Bertone, S.; Pruzzo, C. Occurrence of Vibrio alginolyticus in Ligurian coast rock pools (Tyrrhenian Sea, Italy) and its association with the copepod Tigriopus fulvus (Fisher 1860). Appl. Environ. Microbiol. 1993, 59, $1960-1962$. [CrossRef]

65. Lipp, E.K.; Rivera, I.N.G.; Gil, A.I.; Espeland, E.M.; Choopun, N.; Louis, V.R.; Russek-Cohen, E.; Huq, A.; Colwell, R.R. Direct detection of Vibrio cholerae and ctxA in Peruvian coastal water and plankton by PCR. Appl. Environ. Microbiol. 2003, 69, 3676-3680. [CrossRef]

66. Wai, S.N.; Mizunoe, Y.; Yoshida, S. How Vibrio cholerae survive during starvation. FEMS Microbiol. Lett. 1999, $180,123-131$. [CrossRef]

67. Cottrell, M.T.; Wood, D.N.; Yu, L.; Kirchman, D.L. Selected chitinase genes in cultured and uncultured marine bacteria in the alpha and gamma-subclasses of the proteobacteria. Appl. Environ. Microbiol. 2000, 66, 1195-1201. [CrossRef]

68. Riemann, L.; Azam, F. Widespread N-acetyl-D-glucosamine uptake among pelagic marine bacteria and its ecological implications. Appl. Environ. Microbiol. 2002, 68, 5554-5562. [CrossRef]

69. Pruzzo, C.; Vezzulli, L.; Colwell, R.R. Global impact of Vibrio cholerae interactions with chitin. Environ. Microbiol. 2008, 10, 1400-1410. [CrossRef]

70. Keyhani, N.O.; Roseman, S. Physiological aspects of chitin catabolism in marine bacteria. Biochim. Biophys. Acta 1999, 1473, 108-122. [CrossRef]

71. Meibom, K.L.; Blokesch, M.; Dolganov, N.A.; Wu, C.Y.; Schoolnik, G.K. Chitin induces natural competence in Vibrio cholerae. Science 2005, 310, 1824-1827. [CrossRef]

72. Blokesch, M. The lifestyle of Vibrio cholera fosters gene transfers. Microbe 2014, 9, 64-70.

73. Sawabe, T.; Setogushi, N.; Inoue, S.; Tanaka, R.; Ootsubo, M.; Yoshimizu, M.; Ezura, Y. Acetic acid production of Vibrio halioticoli from alginate: A possible role for establishment of abalone- $V$. halioticoli association. Aquaculture 2003, 219, 671-679. [CrossRef]

74. Zampieri, A.; Babbucci, M.; Carraro, L.; Milan, M.; Fasolato, L.; Cardazzo, B. Combining Culture-dependent and cultureindependent methods: New methodology insight on the Vibrio community of Ruditapes philippinarum. Foods 2021, $10,1271$. [CrossRef]

75. Grimes, D.J.; Stemmler, J.; Hada, H.; May, E.B.; Maneval, D.; Hetrick, F.M.; Jones, R.T.; Stoskopf, M.; Colwell, R.R. Vibrio species associated with mortality of sharks held in captivity. Microb. Ecol. 1984, 10, 271-282. [CrossRef]

76. Ringo, E.; Birkbeck, T.H. Intestinal microflora of fish larvae and fry. Aquacult. Res. 1999, 30, 73-93. [CrossRef]

77. Rosenberg, E.; Ben-Haim, Y. Microbial diseases of corals and global warming. Environ. Microbiol. 2002, 4, 318-326. [CrossRef]

78. Vandenberghe, J.; Thompson, F.L.; Gomez-Gil, B.; Swings, J. Phenotypic diversity amongst Vibrio isolates from marine aquaculture systems. Aquaculture 2003, 219, 9-20. [CrossRef]

79. Laviad-Shitrit, S.; Izhaki, I.; Halpern, M. Accumulating evidence suggests that some waterbird species are potential vectors of Vibrio cholerae. PLoS Pathog. 2019, 15, e1007814. [CrossRef]

80. Passalacqua, P.L.; Zavatta, E.; Bignami, G.; Serraino, A.; Serratore, P.; Studiorum, A.M.; Emilia, O. Occurrence of Vibrio parahaemolyticus, Vibrio cholerae and Vibrio vulnificus in the clam Ruditapes philippinarum (Adams \& Reeve, 1850) from Emilia Romagna and Sardinia, Italy. Ital. J. Food Saf. 2016, 5, 41-46. [CrossRef]

81. Romero, A.; Costa, M.D.; Forn-Cuni, G.; Balseiro, P.; Chamorro, R.; Dios, S.; Figueras, A.; Novoa, B. Occurrence, seasonality and infectivity of Vibrio strains in natural populations of mussels Mytilus galloprovincialis. Dis. Aquat. Org. 2014, 108, 149-163. [CrossRef]

82. Lattos, A.; Bitchava, K.; Giantsis, A.I.; Theodorou, J.A.; Batargias, C.; Michaelidis, B. The implication of Vibrio bacteria in the winter mortalities of the critically endangered Pinna nobilis. Microorganisms 2021, 9, 922. [CrossRef]

83. Brown, B.; Dunne, R.; Goodson, M.; Douglas, A. Experience shapes the susceptibility of a reef coral to bleaching. Coral Reefs 2002, 21, 19-126. [CrossRef]

84. Richardson, L.L.; Goldberg, W.M.; Kuta, K.G. Florida's mystery coral-killer identified. Nature 1998, 392, 557-558. [CrossRef]

85. Sutherland, K.P.; Porter, J.W.; Torres, C. Disease and immunity in Caribbean and Indo-Pacific zooxanthellate corals. Mar. Ecol. Prog. Ser. 2004, 266, 273-302. [CrossRef]

86. Rosenberg, E.; Falkovitz, L. The Vibrio shiloi/Oculina patagonica model system of coral bleaching. Ann. Rev. Microbiol. 2004, 58, 143-159. [CrossRef] 
87. Banin, E.; Israel, Y.; Kushmaro, T.; Loya, A.; Orr, Y.; Rosenberg, E. Penetration of the coral-bleaching bacterium Vibrio shiloi into Oculina patagonica. Appl. Environ. Microbiol. 2000, 66, 3031-3036. [CrossRef]

88. Ben-Haim, Y.; Rosenberg, E. A novel Vibrio sp. pathogen of the coral Pocillopora damicornis. Mar. Biol. 2002, 141, 47-55.

89. Hoffmann, M.; Fischer, M.; Ottesen, A.; McCarthy, P.J.; Lopez, J.V.; Brown, E.W.; Monday, S.R. Population dynamics of Vibrio spp. associated with marine sponge microcosms. ISME J. 2010, 4, 1608-1612. [CrossRef]

90. Schwarz, J.R.; Walder, J.D.; Colwell, R.R. Deep-sea bacteria: Growth and utilization of hydrocarbons at ambient and in situ pressure. Appl. Microbiol. 1974, 28, 982-986. [CrossRef]

91. Raguénès, G.; Christen, R.; Guezennec, J.; Pignet, P.; Barbier, G. Vibrio diabolicus sp. nov., a new polysaccharide-secreting organism isolated from a deep-sea hydrothermal vent Polychaete annelid, Alvinella pompejana. Int. J. Syst. Evol. Microbiol. 1997, 47, 989-995. [CrossRef]

92. Hasan, N.A.; Grim, C.J.; Lipp, E.K.; Rivera, I.N.; Chun, J.; Haley, B.J.; Taviani, E.; Choi, S.Y.; Hoq, M.; Munk, A.C.; et al. Deep-sea hydrothermal vent bacteria related to human pathogenic Vibrio species. Proc. Natl. Acad. Sci. USA 2015, 112, E2813-E2819. [CrossRef]

93. Lightner, D.V.; Redman, R.M. Shrimp diseases and current diagnostic methods. Aquaculture 1998, 164, 201-220. [CrossRef]

94. Leano, E.M.; Lavilla-Pitogo, C.R.; Paner, M.G. Bacterial flora in the hepatopancreas of pond-reared Penaeus monodon juveniles with luminous vibriosis. Aquaculture 1998, 164, 367-374. [CrossRef]

95. Austin, B.; Austin, D.A. Bacterial Fish Pathogens: Disease of Farmed and Wild Fish, 3rd ed.; Springer-Verlag KG: Berlin, Germany, 1999; pp. 499-601.

96. Borrego, J.J.; Castro, D.; Luque, A.; Paillard, C.; Maes, P.; Garcia, M.T.; Ventosa, A. Vibrio tapetis sp. nov., the causative agent of the brown ring disease affecting cultured clams. Int. J. Syst. Bacteriol. 1996, 46, 480-484. [CrossRef]

97. Lee, K.K.; Yu, S.R.; Chen, F.R.; Yang, T.I.; Liu, P.C. Virulence of Vibrio alginolyticus isolated from diseased tiger prawn, Penaeus monodon. Curr. Microbiol. 1996, 32, 229-231. [CrossRef]

98. Lambert, C.; Nicolas, J.L.; Cilia, V.; Corre, S. Vibrio pectenicida sp. nov., a pathogen of scallop (Pecten maximus) larvae. Int. J. Syst. Bacteriol. 1998, 48, 481-487. [CrossRef]

99. Diggles, B.K.; Carson, J.; Hine, P.M.; Hickman, R.W.; Tait, M.J. Vibrio species associated with mortalities in hatchery-reared turbot (Colistium nudipinnis) and brill (C. guntheri) in New Zealand. Aquaculture 2000, 183, 1-12. [CrossRef]

100. Olafsen, J.A. Interactions between fish larvae and bacteria in marine aquaculture. Aquaculture 2001, 200, 223-247. [CrossRef]

101. Mechri, B.; Medhioub, A.; Medhioub, M.N.; Aouni, M. Diversity of Vibrionaceae associated with Ruditapes decussatus hatchery in Tunisia. Ann. Microbiol. 2012, 62, 597-606. [CrossRef]

102. Stabili, L.; Di Salvo, M.; Alifano, P.; Tala, A. An integrative, multiparametric approach for the comprehensive assessment of microbial quality and pollution in aquaculture systems. Microb. Ecol. 2021. [CrossRef]

103. Urbanczyk, H.; Ast, J.C.; Higgins, M.J.; Carson, J.; Dunlap, P.V. Reclassification of Vibrio fischeri, Vibrio logei, Vibrio salmonicida and Vibrio wodanis as Aliivibrio fischeri gen. nov., comb. nov., Aliivibrio logei comb. nov., Aliivibrio salmonicida comb. nov. and Aliivibrio wodanis comb. nov. Int. J. Syst. Evol. Microbiol. 2007, 57, 2823-2829. [CrossRef]

104. Urbanczyk, H.; Ast, J.C.; Dunlap, P.V. Phylogeny, genomics, and symbiosis of Photobacterium. FEMS Microbiol. Rev. 2011, 35, 324-342. [CrossRef] [PubMed]

105. Dunlap, P.V.; Nakamura, M. Functional morphology of the luminescence system of Siphamia versicolor (Perciformes: Apogonidae), a bacterially luminous coral reef fish. J. Morphol. 2011, 272, 897-909. [CrossRef] [PubMed]

106. Dunlap, P.V.; Davis, K.M.; Tomiyama, S.; Fujino, M.; Fukui, A. Developmental and microbiological analysis of the inception of bioluminescent symbiosis in the marine fish Nuchequula nuchalis (Perciformes: Leiognathidae). Appl. Environ. Microbiol. 2008, 74, 7471-7481. [CrossRef] [PubMed]

107. Ast, J.C.; Cleenwerck, I.; Engelbeen, K.; Urbanczyk, H.; Thompson, F.L.; De Vos, P.; Dunlap, P.V. Photobacterium kishitanii sp. nov., a luminous marine bacterium symbiotic with deep-sea fishes. Int. J. Syst. Evol. Microbiol. 2007, 57, 2073-2078. [CrossRef]

108. McFall-Ngai, M.J.; Morin, J.G. Camouflage by disruptive illumination in leiognathids, a family of shallow water bioluminescent fishes. J. Exp. Biol. 1991, 156, 119-137. [CrossRef]

109. Woodland, D.J.; Cabanban, A.S.; Taylor, V.M.; Taylor, R.J. A synchronized rhythmic flashing light display by schooling Leiognathus splendens (Leiognathidae: Perciformes). Mar. Freshw. Res. 2002, 53, 159-162. [CrossRef]

110. Kimura, S.; Dunlap, P.V.; Peristiwady, T.; Lavilla-Pitogo, C.R. The Leiognathus aureus complex (Perciformes: Leiognathidae) with the description of a new species. Ichthyol. Res. 2003, 50, 221-232. [CrossRef]

111. Wada, M.; Azuma, N.; Mizuno, N.; Kurokura, H. Transfer of symbiotic luminous bacteria from parental Leiognathus nuchalis to offspring. Mar. Biol. 1999, 135, 683-687. [CrossRef]

112. Haygood, M.G.; Tebo, B.M.; Nealson, K.H. Luminous bacteria of a monocentrid fish (Monocentris japonicus) and two anomalopid fish (Photoblepharon palpebratus and Kryptophaneron alfredi): Population sizes and growth within the light organs, and rates of release into the seawater. Mar. Biol. 1984, 78, 249-254. [CrossRef]

113. Gould, A.L.; Fritts-Penniman, A.; Gaisiner, A. Museum genomics illuminate the high specificity of a bioluminescent symbiosis for a genus of reef fish. Front. Ecol. Evol. 2021, 9, 630207. [CrossRef]

114. Herring, P.J.; Clarke, M.R.; von Boletzky, S.; Ryan, K.P. The light organs of Sepiola atlantica and Spirula spirula (Mollusca: Cephalopoda): Bacterial and intrinsic systems in the order Sepioidea. J. Mar. Biol. Assoc. 1981, 61, 901-916. [CrossRef] 
115. Fidopiastis, P.M.; von Boletzky, S.; Ruby, E.G. A New Niche for Vibrio logei, the predominant light organ symbiont of squids in the genus Sepiola. J. Bacteriol. 1998, 180, 59-64. [CrossRef] [PubMed]

116. Nishiguchi, M.K. Temperature affects species distribution in symbiotic populations of Vibrio spp. Appl. Env. Microbiol. 2000, 66, 3550-3555. [CrossRef] [PubMed]

117. Tischler, A.H.; Hodge-Hanson, K.M.; Visick, K.L. Vibrio fischeri-Squid Symbiosis; John Wiley \& Sons, Ltd.: Chichester, UK, 2019. [CrossRef]

118. Nyholm, S.V.; Stabb, E.V.; Ruby, E.G.; McFall-Ngai, M.J. Establishment of an animal-bacterial association: Recruiting symbiotic vibrios from the environment. Proc. Natl. Acad. Sci. USA 2000, 97, 10231-10235. [CrossRef] [PubMed]

119. Norsworthy, A.N.; Visick, K.L. Gimme shelter: How Vibrio fischeri successfully navigates an animal's multiple environments. Front. Microbiol. 2013, 4, 356. [CrossRef] [PubMed]

120. Altura, M.A.; Heath-Heckman, E.A.C.; Gillette, A.; Kremer, N.; Krachler, A.M.; Brennan, C.; Ruby, E.G.; Orth, K.; McFall-Ngai, M.J. The first engagement of partners in the Euprymna scolopes-Vibrio fischeri symbiosis is a two-step process initiated by a few environmental symbiont cells. Environ. Microbiol. 2013, 15, 2937-2950. [CrossRef]

121. Nyholm, S.V.; McFall-Ngai, M.J. The winnowing: Establishing the squid-Vibrio symbiosis. Nat. Rev. Microbiol. 2004, 2, 632-642. [CrossRef]

122. Aschtgen, M.S.; Brennan, C.A.; Nikolakakis, K.; Cohen, S.; McFall-Ngai, M.; Ruby, E.G. Insights into flagellar function and mechanism from the squid-vibrio symbiosis. NPJ Biofilms Microbiomes 2019, 5, 32. [CrossRef]

123. Millikan, D.S.; Ruby, E.G. Alterations in Vibrio fischeri motility correlate with a delay in symbiosis initiation and are associated with additional symbiotic colonization defects. Appl. Environ. Microbiol. 2002, 68, 2519-2528. [CrossRef]

124. Wier, A.M.; Nyholm, S.V.; Mandel, M.J.; Massengo-Tiassé, R.P.; Schaefer, A.L.; Koroleva, I.; Splinter-BonDurant, S.; Brown, B.; Manzella, L.; Snir, E.; et al. Transcriptional patterns in both host and bacterium underlie a daily rhythm of anatomical and metabolic change in a beneficial symbiosis. Proc. Natl. Acad. Sci. USA 2010, 107, 2259-2264. [CrossRef]

125. McFall-Ngai, M.J.; Ruby, E.G. Symbiont recognition and subsequent morphogenesis as early events in an animal-bacterial mutualism. Science 1991, 254, 1491-1494. [CrossRef] [PubMed]

126. Gray, K.M.; Greenberg, E.P. Physical and functional maps of the luminescence gene cluster in an autoinducer-deficient Vibrio fischeri strain isolated from a squid light organ. J. Bacteriol. 1992, 174, 4384-4390. [CrossRef] [PubMed]

127. Verma, S.C.; Miyashiro, T. Quorum sensing in the squid-Vibrio symbiosis Int. J. Mol. Sci. 2013, 14, 16386-16401. [CrossRef] [PubMed]

128. Lupp, C.; Urbanowski, M.; Greenberg, E.P.; Ruby, E.G. The Vibrio fischeri quorum-sensing systems ain and lux sequentially induce luminescence gene expression and are important for persistence in the squid host. Mol. Microbiol. 2003, 50, 319-331. [CrossRef] [PubMed]

129. Baker-Austin, C.; Oliver, J.D.; Alamo, M.; Ali, A.; Waldor, M.K.; Qadri, F.; Martinez-Urtaza, J. Vibrio spp. infections. Nat. Rev. Dis. Primers 2018, 4, 8. [CrossRef] [PubMed]

130. 130. CDC (Center for Disease Control and Prevention). Preliminary incidence and trends of infections with pathogens transmitted commonly through food-Foodborne Diseases Active Surveillance Network, 10 U.S. Sites, 2016-2019. MMWR 2020, 69, 509-514.

131. Wachsmuth, I.K.; Blake, P.A.; Olsvik, O. Vibrio cholerae and cholera. In Molecular to Global Perspectives; ASM Press: Washington, DC, USA, 1994.

132. Finkelstein, R.; Edelstein, S.; Mahamid, G. Fulminant wound infections due to Vibrio vulnificus. Isr. Med. Assoc. J. 2002, 4, 654-655. [PubMed]

133. Singleton, F.L.; Attwell, R.; Jangi, S.; Colwell, R.R. Effects of temperature and salinity on Vibrio cholerae growth. Appl. Environ. Microbiol. 1982, 44, 1047-1058. [CrossRef]

134. ECDC (European Centre for Disease Prevention and Control). Cholera. In ECDC. Annual Epidemiological Report for 2019; ECDC: Stockholm, Sweden, 2021.

135. Ramamurthy, T.; Mutreja, A.; Weill, F.X.; Das, B.; Ghosh, A.; Nair, G.B. Revisiting the global epidemiology of cholera in conjunction with the genomics of Vibrio cholera. Front. Public Health 2019, 7, 237. [CrossRef]

136. Islam, M.S.; Mahmuda, S.; Morshed, M.G.; Bakht, H.B.M.; Khan, M.N.H.; Sack, R.B.; Sack, D.A. Role of cyanobacteria in the persistence of Vibrio cholerae O139 in saline microcosms. Can. J. Microbiol. 2004, 50, 127-131. [CrossRef]

137. Reidl, J.; Klose, K.E. Vibrio cholerae and cholera: Out of the water and into the host. FEMS Microbiol. Rev. 2002, 26, 125-139. [CrossRef] [PubMed]

138. Cotter, P.A.; DiRita, V.J. Bacterial virulence gene regulation: An evolutionary perspective. Annu. Rev. Microbiol. 2000, 54, 519-565. [CrossRef] [PubMed]

139. Yu, R.R.; DiRita, V.J. Regulation of gene expression in Vibrio cholerae by ToxT involves both antirepression and RNA polymerase stimulation. Mol. Microbiol. 2002, 43, 119-134. [CrossRef] [PubMed]

140. Bina, J.; Zhu, J.; Dziejman, M.; Faruque, S.; Calderwood, S.; Mekalanos, J. ToxR regulon of Vibrio cholerae and its expression in vibrios shed by cholera patients. Proc. Natl. Acad. Sci. USA 2003, 100, 2801-2806. [CrossRef]

141. Alter, T.; Appel, B.; Bartelt, E.; Dieckmann, R.; Eichhorn, C.; Erler, R.; Frank, C.; Gerdts, G.; Gunzer, F.; Hühn, S.; et al. VibrioInfektionen durch Lebensmittel und Meerwasser. Das Netzwerk "VibrioNet" stellt sich vor. Bundesgesundheitsblatt-Gesundh. -Gesundh. 2011, 54, 1235-1240. [CrossRef] 
142. Araj, G.F.; Taleb, R.; El Beayni, N.K.; Goksu, E. Vibrio albensis: An unusual urinary tract infection in a healthy male. J. Infect. Public Health 2019, 12, 712-713. [CrossRef]

143. Fernández-Bravo, A.; Ballester, F.; Pujol, I.; Gomez-Bertomeu, F.; Martí, C.; Rezusta, A.; Ferrer-Cerón, I.; Aspiroz, C.; Puyod, M.J.; Figueras, M.J. Vibrio alginolyticus infections: Report of two cases from Spain with literature review. J. Med. Microb. Diagn. 2019, 8, 298. [CrossRef]

144. Albuquerque, A.; Cardoso, H.; Pinheiro, D.; Macedo, G. Vibrio cholerae non-O1 and non-O139 bacteremia in a non-traveler Portuguese cirrhotic patient: First case report. Gastroenterol. Hepatol. 2013, 36, 309-310. [CrossRef]

145. Montemayor, K.; Raju, S.; Sahetya, S.K. A fatal case of Vibrio cholerae bacteremia in a patient with stage IIIC ovarian carcinoma. American Thoracic Society International Conference Abstracts, C54. Critical Care Case Reports: Sepsis. Am. J. Respir. Crit. Care Med. 2016, 193, AS398.

146. Kechker, P.; Senderovich, Y.; Ken-Dror, S.; Laviad-Shitrit, S.; Arakawa, E.; Halpern, M. Otitis media caused by V. cholerae O100: A case report and review of the literature. Front. Microbiol. 2017, 8, 1619. [CrossRef]

147. Chen, W.-D.; Lai, L.-J.; Hsu, W.-H.; Huang, T.-Y. Vibrio cholerae non-O1-the first reported case of keratitis in a healthy patient. BMC Infect. Dis. 2019, 19, 916. [CrossRef] [PubMed]

148. Brehm, T.T.; Berneking, L.; Rohde, H.; Chistner, M.; Schlickewei, C.; Martins, M.S.; Schmiedel, S. Wound infection with Vibrio harveyi following a traumatic leg amputation after a motorboat propeller injury in Mallorca, Spain: A case report and review of literature. BMC Infect. Dis. 2020, 20, 104. [CrossRef] [PubMed]

149. Akram, A.; Stevens, R.P.; Konecny, P. Photobacterium damselae and Vibrio harveyi hand infection from marine exposure. Med. J. Aust. 2015, 203, 224-225.e1. [CrossRef]

150. Jensen, J.; Jellinge, M.E. Severe septic shock and cardiac arrest in a patient with Vibrio metschnikovii: A case report. J. Med. Case Rep. 2014, 8, 348. [CrossRef]

151. Konechnyi, Y.; Khorkavyi, Y.; Ivanchuk, K.; Kobza, I.; Sekowska, A.; Korniychuk, O. Vibrio metschnikovii: Current state of knowledge and discussion of recently identified clinical case. Clin. Case Rep. 2021, 9, 2236-2244. [CrossRef]

152. Guillod, C.; Ghitti, F.; Mainetti, C. Vibrio parahaemolyticus induced cellulitis and septic shock after a sea beach holiday in a patient with leg ulcers. Case Rep. Dermatol. 2019, 11, 94-100. [CrossRef]

153. França, J.C.B.; Raboni, S.M.; Sanfelice, E.; Polido, D.; Gentili, A.; Marques, F. Vibrio vulnificus infection in Southern Brazil-Case report. An. Bras. Dermatol. 2013, 88, 424-426. [CrossRef]

154. Reitz, K.M.; Allen, P.D.; Hamad, G.G.; Corcos, A. A Case of Vibrio vulnificus septicemia in a patient with gastric bypass surgery. Surg. Infect. Case Rep. 2016, 1, 100-102. [CrossRef]

155. Hendren, N.; Sukumar, S.; Glazer, C.S. Vibrio vulnificus septic shock due to a contaminated tattoo. BMJ Case Rep. 2017, 2017, bcr2017220199. [CrossRef]

156. Guimarães, D.; Ribeiro, L.; Vieira, L.; Coelho, R. Necrotizing fasciitis caused by Photobacterium damselae: The first case in Portugal. Acta Med. Port. 2021, 34, 615-618. [CrossRef]

157. FDA (Food and Drug Administration). Bad Bug Book: Foodborne Pathogenic Microorganisms and Natural Toxins Handbook, 2nd ed.; Lampel, K.A., Al-Khaldi, S., Cahill, S.M., Eds.; FDA: Washington, DC, USA, 2012.

158. Jones, M.K.; Oliver, J.D. Vibrio vulnificus: Disease and pathogenesis. Infect. Immun. 2009, 77, 1723-1733. [CrossRef] [PubMed]

159. Zhang, X.H.; He, X.X.; Austin, B. Vibrio harveyi: A serious pathogen of fish and invertebrates in mariculture. Mar. Life Sci. Technol. 2020, 2, 231-245. [CrossRef] [PubMed]

160. Hundenborn, J.; Thurig, S.; Kommerell, M.; Haag, H.; Nolte, O. Severe wound infection with Photobacterium damselae ssp. damselae and Vibrio harveyi, following a laceration injury in marine environment: A case report and review of the literature. Case Rep. Med. 2013, 2013, 610632. [CrossRef] [PubMed]

161. CDC. Available online: https://www.cdc.gov/vibrio/index.html (accessed on 5 November 2021).

162. Loo, K.Y.; Letchumanan, V.; Law, J.W.F.; Pusparajah, P.; Goh, B.H.; Mutalib, N.S.A.; He, Y.W.; Lee, L.H. Incidence of antibiotic resistance in Vibrio spp. Rev. Aquac. 2020, 12, 2590-2608. [CrossRef]

163. Sack, D.A.; Lyke, C.; McLaughlin, C.; Suwanvanichkij, V. Antimicrobial Resistance in Shigellosis, Cholera and Campylobacteriosis; World Health Organization: Geneva, Switzerland, 2001; 56p.

164. Dutta, D.; Kaushik, A.; Kumar, D.; Bag, S. Foodborne pathogenic vibrios: Antimicrobial resistance. Front. Microbiol. 2021, 2, 638331. [CrossRef]

165. Das, B.; Verma, J.; Kumar, P.; Ghosh, A.; Ramamurthy, T. Antibiotic resistance in Vibrio cholerae: Understanding the ecology of resistance genes and mechanisms. Vaccine 2020, 38 (Suppl. 1), A83-A92. [CrossRef]

166. Elmahdi, S.; DaSilva, L.V.; Parveen, S. Antibiotic resistance of Vibrio parahaemolyticus and Vibrio vulnificus in various countries: A review. Food Microbiol. 2016, 57, 128-134. [CrossRef]

167. Pérez-Duque, A.; Gonzalez-Muñoz, A.; Arboleda-Valencia, J.; Vivas-Aguas, L.J.; Córdoba-Meza, T.; Rodriguez-Rey, G.T.; DíazGuevara, P.; Martinez-Urtaza, J.; Wiesner-Reyes, M. Comparative genomics of clinical and environmental isolates of Vibrio spp. of Colombia: Implications of traits associated with virulence and resistance. Pathogens 2021, 10, 1605. [CrossRef]

168. Baker-Austin, C.; McArthur, J.V.; Tuckfield, R.C.; Najarro, M.; Lindell, A.H.; Gooch, J.; Stepanauskas, R. Antibiotic resistance in the shellfish pathogen Vibrio parahaemolyticus isolated from the coastal water and sediment of Georgia and South Carolina, USA. J. Food Prot. 2008, 71, 2552-2558. [CrossRef] 
169. Dobbs, F.C.; Goodrich, A.L.; Thomson, F.K.; Hynes, W. Pandemic serotypes of vibrio cholerae isolated from ships' ballast tanks and coastal waters: Assessment of antibiotic resistance and virulence genes (tcpA and ctxA). Microb. Ecol. 2013, 65, 969-974. [CrossRef]

170. Verma, J.; Bag, S.; Saha, B.; Kumar, P.; Ghosh, T.S.; Dayal, M.; Senapati, T.; Mehra, S.; Dey, P.; Desigamani, A.; et al. Genomic plasticity associated with antimicrobial resistance in Vibrio cholera. Proc. Natl. Acad. Sci. USA 2019, 116, 6226-6231. [CrossRef] [PubMed]

171. Shaw, K.S.; Goldstein, R.E.R.; He, X.; Jacobs, J.M.; Crump, B.C.; Sapkota, A.R. Antimicrobial susceptibility of Vibrio vulnificus and Vibrio parahaemolyticus recovered from recreational and commercial areas of Chesapeake Bay and Maryland Coastal Bays. PLoS ONE 2014, 9, e89616. [CrossRef] [PubMed]

172. Gxalo, O.; Digban, T.O.; Igere, B.E.; Olapade, O.A.; Okoh, A.I.; Nwodo, U.U. Virulence and antibiotic resistance characteristics of Vibrio isolates from rustic environmental freshwaters. Front. Cel Front. Cell. Infect. Microbiol. 2021, 11, 732001. [CrossRef] [PubMed]

173. Coutinho, F.H.; Tschoeke, D.G.; Clementino, M.M.; Thompson, C.C.; Thompson, F.L. Genomic basis of antibiotic resistance in Vibrio parahaemolyticus strain JPA1. Mem. Inst. Oswaldo Cruz 2019, 114, e190053. [CrossRef] [PubMed]

174. Deng, Y.Q.; Xu, L.W.; Chen, H.X.; Liu, S.L.; Guo, Z.X.; Cheng, C.H.; Ma, H.L.; Feng, J. Prevalence, virulence genes, and antimicrobial resistance of Vibrio species isolated from diseased marine fish in South China. Sci. Rep. 2020, 10, 14329. [CrossRef] [PubMed]

175. Amalina, N.Z.; Santha, S.; Zulperi, D.; Amal, M.N.A.; Yusof, M.T.; Zamri-Saad, M.; Ina-Salwany, Y. Prevalence, antimicrobial susceptibility and plasmid profiling of Vibrio spp. isolated from cultured groupers in Peninsular Malaysia. BMC Microbiol. 2019, 19, 251. [CrossRef] [PubMed]

176. Reverter, M.; Sarter, S.; Caruso, D.; Avarre, J.C.; Combe, M.; Pepey, E.; Pouyaud, L.; Vega-Heredia, S.; de Verdal, H.; Gozlan, R.E. Aquaculture at the crossroads of global warming and antimicrobial resistance. Nat. Commun. 2020, 11, 1870. [CrossRef]

177. CODEX Alimentarius. Guidelines on the Application of General Principles of Food Hygiene to the Control of pathogenic Vibrio in Seafood; CAC/GL 73-2010; FAO: Rome, Italy, 2010; 14p.

178. FAO (Food and Agriculture Organization of the United Nations); WHO (World Health Organization). Selection and Application of Methods for the Detection and Enumeration of Human-Pathogenic Halophilic Vibrio spp. in Seafood: Guidance; FAO and WHO: Geneva, Switzerland, 2016; 74p, Available online: https://apps.who.int/iris/handle/10665/249530 (accessed on 5 November 2021).

179. EFSA (European Food Safety Authority); ECDC (European Centre for Disease Prevention and Control). The European Union One Health 2019 Zoonoses Report. EFSA J. 2021, 19, e6406.

180. CDC (Center for Disease Control and Prevention). Available online: https://www.cdc.gov/vibrio/faq.html (accessed on 5 November 2021).

181. Slifka, K.M.J.; Newton, A.E.; Mahon, B.E. Vibrio alginolyticus infections in the USA, 1988-2012. Epidemiol. Infect. 2017, 145, 1491-1499. [CrossRef]

182. Korea Times. Available online: https://www.koreatimes.co.kr/www/nation/2020/09/119_295392.html (accessed on 5 November 2021).

183. EFSA (EFASA Panel on Biological Hazards, BIOHAZ, EFSA Panel on Contaminants in the Food Chain, CONTAM). Scientific opinion on the minimum hygiene criteria to be applied to clean seawater and on the public health risks and hygiene criteria for bottled seawater intended for domestic use. EFSA J. 2012, 10, 2613. [CrossRef]

184. Osunla, C.A.; Okoh, A.I. Vibrio pathogens: A public health concern in rural water resources in Sub-Saharan Africa. Int. J. Environ. Res. Public Health 2017, 14, 1188. [CrossRef] [PubMed]

185. FAO. The State of World Fisheries and Aquaculture 2020. In Sustainability in Action; Food and Agriculture Organization of the United Nations: Rome, Italy, 2020. [CrossRef]

186. Kabore, S.; Cecchi, P.; Mosser, T.; Toubiana, M.; Traore, O.; Ouattara, A.S.; Traore, A.S.; Barro, N.; Colwell, R.R.; Monfort, P. Occurrence of Vibrio cholerae in water reservoirs of Burkina Faso. Res. Microbiol. 2018, 169, 1-10. [CrossRef] [PubMed]

187. Venohr, M.; Langhans, S.D.; Peters, O.; Holker, F.; Arlinghaus, R.; Mitchell, L.; Wolter, C. The underestimated dynamics and impacts of water-based recreational activities on freshwater ecosystems. Environ. Rev. 2018, 26, 199-213. [CrossRef]

188. EFSA (EFSA Panel on Animal Health and Welfare). Scientific opinion on oyster mortality. EFSA J. 2015, 13, 4122. [CrossRef]

189. Rigos, G.; Katharios, P.; Kogiannou, D.; Cascarano, C.M. Infectious diseases and treatment solutions of farmed greater amberjack Seriola dumerili with particular emphasis in Mediterranean region. Rev. Aquac. 2021, 13, 301-323. [CrossRef]

190. Vezzulli, L.; Colwell, R.R.; Pruzzo, C. Ocean warming and spread of pathogenic Vibrios in the aquatic environment. Microb. Ecol. 2013, 65, 817-825. [CrossRef] [PubMed]

191. Hartnell, R.E.; Stockley, L.; Keay, W.; Rosec, J.P.; Hervio-Heath, D.; Van den Berg, H.; Leoni, F.; Ottaviani, D.; Henigman, U.; Denayer, S.; et al. A pan-European ring trial to validate an International Standard for detection of Vibrio cholerae, Vibrio parahaemolyticus and Vibrio vulnificus in seafoods. Int. J. Food Microbiol. 2019, 288, 58-65. [CrossRef]

192. Wiltshire, K.H.; Manly, B.F.J. The warming trend at Helgoland Roads, North Sea: Phytoplankton response. Helgol. Mar. Res. 2004, 58, 269-273. [CrossRef]

193. Hackbusch, S.; Wichels, A.; Gimenez, L.; Dopke, H.; Gerdts, G. Potentially human pathogenic Vibrio spp. in a coastal transect: Occurrence and multiple virulence factors. Sci. Total Environ. 2020, 707, 136113. [CrossRef]

194. Baker-Austin, C.; Oliver, J.D. Vibrio vulnificus: New insights into a deadly opportunistic pathogen. Environ. Microbiol. 2018, 20, 423-430. [CrossRef] 
195. Larsen, A.K.; Nymo, I.H.; Sorensen, K.K.; Seppola, M.; Rodven, R.; de Bagues, M.P.J.; Al Dahouk, S.; Godfroid, J. Concomitant temperature stress and immune activation may increase mortality despite efficient clearance of an intracellular bacterial infection in Atlantic Cod. Front. Microbiol. 2018, 9, 2963. [CrossRef] [PubMed]

196. Li, Y.F.; Chen, Y.W.; Xu, J.K.; Ding, W.Y.; Shao, A.Q.; Zhu, Y.T.; Wang, C.; Liang, X.; Yang, J.L. Temperature elevation and Vibrio cyclitrophicus infection reduce the diversity of haemolymph microbiome of the mussel Mytilus coruscus. Sci. Rep. $2019,9,16391$. [CrossRef] [PubMed]

197. Stewart, J.R.; Gast, R.J.; Fujioka, R.S.; Solo-Gabriele, H.M.; Meschke, J.S.; Amaral-Zettler, L.A.; del Castillo, E.; Polz, M.F.; Martin, F.; Collier, T.K.; et al. The coastal environment and human health: Microbial indicators, pathogens, sentinels and reservoirs. Environ. Health 2008, 7, S3. [CrossRef] [PubMed] 